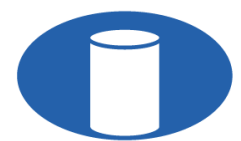

IBRACON Structures and Materials Journal

Revista IBRACON de Estruturas e Materiais

IBRACON

ISSN 1983-4195

ismj.org

ORIGINAL ARTICLE

\title{
Design and verification of reinforced concrete shell elements
}

\section{Dimensionamento e verificação de elementos de casca de concreto armado}

\author{
Marina Vendl Craveiro ${ }^{\mathrm{a}}$ \\ Túlio Nogueira Bittencourt ${ }^{\mathrm{a}}$ \\ João Carlos Della Bella ${ }^{\text {a }}$
}

${ }^{a}$ Universidade de São Paulo - USP, Escola Politécnica, Departamento de Engenharia de Estruturas e Geotécnica, São Paulo, SP, Brasil

Received 10 February 2020

Accepted 07 August 2020

\begin{abstract}
Reinforced concrete shell elements are relevant in several civil and industrial structures. It is important to know the methods for designing and verifying such elements. In this context, the present paper aims at describing the iterative three-layer method proposed by Colombo et al. This method is based on the Model Code/1990, and it can be applied in the design of shell elements. An additional method for verifying reinforced concrete shell elements is also proposed and discussed. This one is based on the multilayer method proposed by Kollegger et al. Formulations as well as numerical examples are presented for both methods. The design proposed by Colombo et al. is verified by using the methodology based on the multilayer method. Although both methods lead to the equilibrium between applied and resistance loads using approximately the same amount of reinforcement, especially for small neutral axes in relation to the element thickness, one may conclude that the three-layer design method has limitations due to not considering strain compatibility along the thickness of the element and due to the impossibility to calculate the compression reinforcement. Although the multilayer method overcomes such limitations, it is a verification method, and more studies about its use in the design of reinforced concrete shell elements are necessary.
\end{abstract}

Keywords: reinforcement, reinforced concrete, design, shell elements, verification.

Resumo: Os elementos de casca de concreto armado podem ser aplicados em diversas estruturas civis e industriais, sendo importante conhecer os métodos de dimensionamento e verificação desses elementos. Dentro desse contexto, o presente trabalho tem como objetivo descrever o método iterativo das três chapas proposto por Colombo et al., o qual se baseia nas ideias do Model Code/1990 e é aplicado no dimensionamento dos elementos de casca. Um método adicional para verificação de elementos de casca de concreto armado também é proposto e discutido. Esse último se baseia no método das multicamadas de Kollegger et al. Tanto as formulações quanto exemplos numéricos de aplicação são apresentados para ambos os métodos. O dimensionamento proposto por Colombo et al. é verificado utilizando a metodologia baseada no método das multicamadas. Embora ambos os métodos levem ao equilíbrio entre esforços solicitantes e resistentes com aproximadamente a mesma quantidade de armadura, sobretudo para linhas neutras pequenas em relação à espessura do elemento, pode-se concluir que o método das três chapas possui limitações devido a não consideração da compatibilidade de deformações ao longo da espessura do elemento e à impossibilidade de dimensionar armaduras de compressão. O método das multicamadas supera tais limitações, mas é, a princípio, um método de verificação, havendo necessidade de mais estudos sobre a sua utilização no dimensionamento de elementos de casca de concreto armado.

Palavras-chave: armadura, concreto armado, dimensionamento, elementos de casca, verificação.

How to cite: M. V. Craveiro, T. N. Bittencourt, and J. C. Della Bella, "Design and verification of reinforced concrete shell elements," Rev. IBRACON Estrut. Mater., vol. 14, no. 3, e14305, 2021, https://doi.org/10.1590/S1983-41952021000300005

Corresponding author: Marina Vendl Craveiro. E-mail: marina.craveiro@usp.br

Financial support: None.

Conflict of interest: Nothing to declare. 


\section{INTRODUCTION}

\subsection{Overview}

The behavior of concrete structures can be analyzed through models composed of basic structural elements. Such elements are classified according to the geometry and the loads acting on them. NBR 6118/2014 [1], for example, depending on geometry, separates the structural elements into linear elements and surface elements. The linear elements are those in which the longitudinal dimension is relatively larger than the dimensions of the cross section. They are defined by the longitudinal axis that crosses the centroids of the cross sections and by the dimensions of the cross sections perpendicular to the axis. Surface elements, on the other hand, are those in which one dimension, usually called thickness, is relatively smaller than the other two dimensions. They are defined by the average surface and by the thicknesses perpendicular to it. Within this classification, NBR 6118/2014 [1] also differentiates several types of structural elements according to the loads to which they are subjected. The linear elements are:

a) beams, in which bending is predominant;

b) columns, in which compressive axial forces are predominant;

c) ties, in which tensile axial forces are predominant;

d) arches, in which compressive axial forces are predominant, with or without bending loads.

The surface elements, in their turn, are:

a) plates, in which the loads act predominantly normal to their plane;

b) membranes, in which the loads are predominantly contained in their plane;

c) shells, which consist in non-flat surface elements;

d) shear walls, which consist in either flat surface elements or cylindrical shells subjected predominantly to compression and with the smallest dimension of the cross section smaller than 1/5 of the largest dimension.

Regarding the modeling of surface structures, the plate elements can represent flat surfaces subjected to loads normal to their plane and are able to resist such loads by means of bending effects, that is, bending moments in both directions $\left(\mathrm{M}_{\mathrm{x}}\right.$ and $\left.\mathrm{M}_{\mathrm{y}}\right)$, torsional moment $\left(\mathrm{M}_{\mathrm{xy}}\right)$ and shear forces in both directions $\left(\mathrm{V}_{\mathrm{x}}\right.$ and $\left.\mathrm{V}_{\mathrm{y}}\right)$, outside the plane of the plate. Figure 1a illustrates the resulting loads in a plate element. The membrane elements, as they are subjected to loads contained in their plane, resist the external loads by means of membrane loads, that is, axial forces in both directions $\left(\mathrm{N}_{\mathrm{x}}\right.$ and $\left.\mathrm{N}_{\mathrm{y}}\right)$ and shear force $\left(\mathrm{N}_{\mathrm{xy}}\right)$, contained in the plane of the membrane. Figure $1 \mathrm{~b}$ illustrates the resulting loads in a membrane element used to model flat structures subjected to loads contained in their plane. The shell elements, in their turn, can be subjected to both loads normal to their plane and loads contained in their plane, resisting such loads by means of bending and membrane loads ([2] and [3]). It is assumed here that any elements under such conditions, flat or non-flat, can be considered shell elements, extending, therefore, the definition of shells given by NBR 6118/2014 [1]. Figure 1c illustrates the resulting loads in a flat shell element. The flat elements are the elements most used in practice to represent shell structures, being also useful for modeling curved structures, since they can be represented by several flat elements. Thus, non-flat shell elements will not be addressed in the present paper. Another point to be commented on is related to the evaluation of the loads illustrated in Figure 1. In general, such loads are obtained in practice from elastic-linear analyses, which must employ appropriate theories according to the relationship between the element thickness and the structure span, taking into account or not shear strains.

The reinforced concrete shells can be used in the design of roofs, silos, offshore platforms, industrial facilities, nuclear power plants, tunnels, dam structures, etc. Figure 2 shows, for example, the bottom discharge of a dam, which is subjected to loads normal to its plane and to loads contained in its plane. It can be modeled with the flat shell elements presented in Figure 1c. Shells consist in a powerful structural system to resist the applied loads, even with large spans and thin sections. The loads to which these structures are subjected can be determined by numerical elastic-linear analysis techniques, such as the finite element method. The difficulty of designing such structures, however, is their detailing, since it must take into account the nonlinear constitutive behavior of concrete and steel to evaluate the structure strength ([4] and [5]). It is noteworthy that the nonlinear analysis of reinforced concrete structures is also possible [6]. However, since the dimensions and the reinforcement should already be pre-defined and the computational cost is significant, such analysis is usually used in more complex structures and in verification and not designing procedures. 


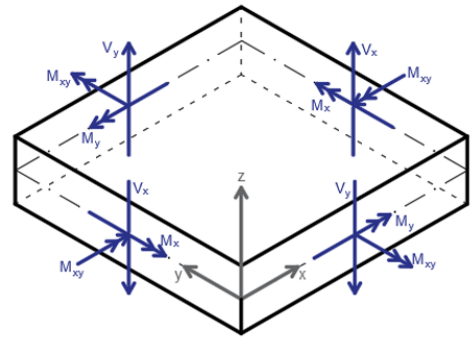

(a)

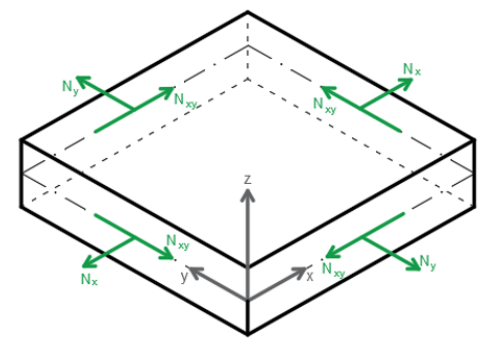

(b)

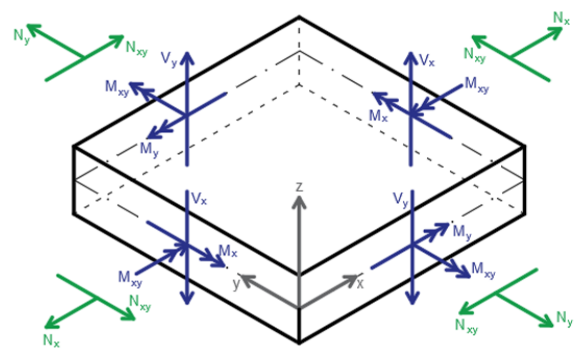

(c)

Figure 1. Surface element loads. a) Plate element. b) Membrane element. c) Shell element.

Many researchers have studied how to determine the reinforcement of shell elements subjected to $M_{x}, M_{y}, M_{x y}, N_{x}$, $\mathrm{N}_{\mathrm{y}}$ and $\mathrm{N}_{\mathrm{xy}}$, defined per unit length. Among them, it can be mentioned Brandurn-Nielsen [7], Gupta [8] and Lourenço and Figueiras [9]. The basic idea of the authors is to resist such loads by tension in the reinforcement and compression in the concrete. Dividing the reinforced concrete shell element into two outer layers of concrete with reinforcement arranged orthogonally in both directions in each layer, Gupta [8] created an iterative trial-and-error method for the determination of reinforcement based on the equilibrium conditions and on the principle of minimum resistance. Gupta [8] seeks to achieve the smallest possible strength of the element, that is, the smallest resistance loads capable of equilibrating the applied loads, with the maximum use of concrete and steel materials. So, it is assumed that the failure occurs with a unitary relationship between the resistance loads and the applied loads. It is worth mentioning that Gupta [8] studied only the case in which reinforcement is necessary in both concrete layers.

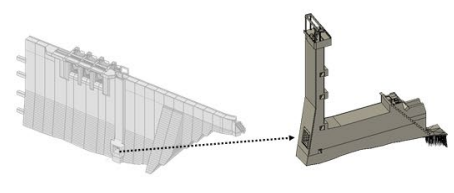

(a)

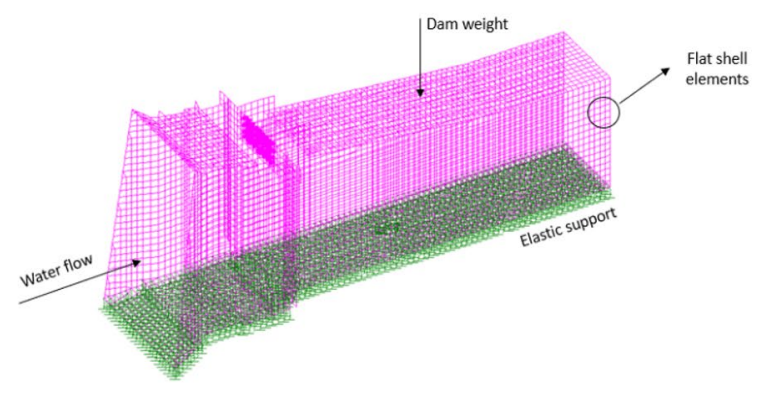

(b)

Figure 2. Use of flat shell elements to model a bottom discharge of a dam. a) Structure. b) Model. 
Lourenço and Figueiras [9] proposed an automated method for calculating the shell reinforcement based on the three-layer method proposed by Model Code/1990 [10], extending the idea of Gupta [8] also for cases in which the reinforcement is not necessary in one or two outer layers. The three-layer method, also present in Model Code/2010 [11], consists in the idealization of the shell element as a superposition of three layers. The two outer layers are responsible for resisting the moments and the membrane forces, and the central layer is responsible for resisting transverse shear. Colombo et al. [12] were also based on this three-layer method to develop an algorithm for reinforced concrete shell design.

Another line of analysis of shell elements consists in that followed by Kollegger et al. [13], which is also indicated in Comité Euro-International du Betón [14]. Such analysis divides the shell element into layers that have uniform stress and strain states. Assuming linear variation of strain along the element thickness, the strain state can be estimated from the element center strains and the curvatures. From the strains, the stresses can be estimated by using suitable constitutive models for concrete and steel. These stresses are used to determine the resistance loads of the element. The determination of the element center strains and the curvatures compatible with the applied loads can be done with the Newton-Raphson nonlinear iterative method, imposing the equilibrium between the resistance and applied loads. This is a method to be used for element verification, but it can also be expanded to design by means of iterative procedures.

\subsection{Objectives and methodology}

Given the great applicability of shells in civil and industrial structures, it is important to compare the existing methods for designing and verifying reinforced concrete shell elements. In this context, the objective of the work is to describe the methodology developed by Colombo et al. [12] for designing reinforced concrete shells and to present a methodology based on the idea proposed by Kollegger et al. [13] for verifying such shells. The work will be developed through the presentation of formulations and numerical examples as well as comparisons between the two methodologies. It is worth noting that the focus of the research is only on the design and verification of shell elements from the point of view of resistance. The work will not address the stability issues of shell elements, which, in practice, also need to be taken into account, especially in the case of thin shells.

\section{DESIGN BY THE THREE-LAYER METHOD}

The formulation proposed by Colombo et al. [12] for designing reinforced concrete shells will be presented below. It can be applied to both thin and thick shells, requiring only that the loads are obtained accordingly. Numerical applications will also be detailed.

\subsection{Formulation}

The three-layer method idealizes the reinforced concrete shell element as a superposition of three layers/membranes (Figure 3a). The outer layers are designed to resist the moments $M_{x}, M_{y}$ and $M_{x y}$ and the membrane forces $N_{x}, N_{y}$ and $\mathrm{N}_{\mathrm{xy}}$. The central layer is responsible for resisting the transverse shear. Separating the study of the outer layers from the study of the central layer, the idea is that $M_{x}, M_{y}, M_{x y}, N_{x}, N_{y}$ and $N_{x y}$ are resisted by membrane forces in each of the outer layers. The membrane forces of the upper and lower layers may be determined such that the loads applied to the shell element are equilibrated by the membrane forces of both layers. Figure 4 illustrates the proposed equilibrium and Equations 1 to 6 determine the membrane forces in each outer layer by means of the imposition of such equilibrium. The forces $\mathrm{N}_{\mathrm{x}\left(\mathrm{z}^{+}\right)}, \mathrm{N}_{\mathrm{y}\left(\mathrm{z}^{+}\right)}$and $\mathrm{N}_{\mathrm{xy}\left(\mathrm{z}^{+}\right)}$correspond to the membrane forces of the layer of face $\mathrm{z}^{+}$of the shell element and the forces $\mathrm{N}_{\mathrm{x}(\mathrm{z}-)}, \mathrm{N}_{\mathrm{y}(\mathrm{z}-)}$ and $\mathrm{N}_{\mathrm{xy}}(\mathrm{z}-)$ correspond to the membrane forces of the layer of face $\mathrm{z}-$ of the shell element. The dimensions $\mathrm{a}_{\left(\mathrm{z}^{+}\right)}, \mathrm{a}_{(\mathrm{z}-)}, \mathrm{h}_{\left(\mathrm{z}^{+}\right)}, \mathrm{h}_{(\mathrm{z}-)}, \mathrm{h}_{\mathrm{sx}\left(\mathrm{z}^{+}\right)}, \mathrm{h}_{\mathrm{sx}\left(\mathrm{z}_{-}\right)}, \mathrm{h}_{\mathrm{sy}\left(\mathrm{z}^{+}\right)}$and $\mathrm{h}_{\mathrm{sy}(\mathrm{z}-)}$, in their turn, are indicated in Figure $3 \mathrm{~b}$.

$$
\begin{aligned}
& \Sigma M_{\text {center of the layer offace } z-}=0 \rightarrow N_{x(z+)}=\frac{N_{x} h_{(z-)}+M_{x}}{\left(h_{(z+)}+h_{(z-)}\right)} \\
& \Sigma M_{\text {center of the layer of face } z^{-}}=0 \rightarrow N_{y(z+)}=\frac{N_{y} h_{(z-)}+M_{y}}{\left(h_{(z+)}+h_{(z-)}\right)}
\end{aligned}
$$


$\Sigma M_{\text {center of the layer of face } z-}=0 \rightarrow N_{x y(z+)}=\frac{N_{x y} h_{(z-)}+M_{x y}}{\left(h_{(z+)}+h_{(z-)}\right)}$

$M_{\text {center of the layer of face } z+}=0 \rightarrow N_{x(z-)}=\frac{N_{x} h_{(z+)}-M_{x}}{\left(h_{(z+)}+h_{(z-)}\right)}$

$\Sigma M_{\text {center of the layer of face } z+}=0 \rightarrow N_{y(z-)}=\frac{N_{y} h_{(z+)}-M_{y}}{\left(h_{(z+)}+h_{(z-)}\right)}$

$\Sigma M_{\text {center of the layer of face } z+}=0 \rightarrow N_{x y(z-)}=\frac{N_{x y} h_{(z+)}-M_{x y}}{\left(h_{(z+)}+h_{(z-)}\right)}$

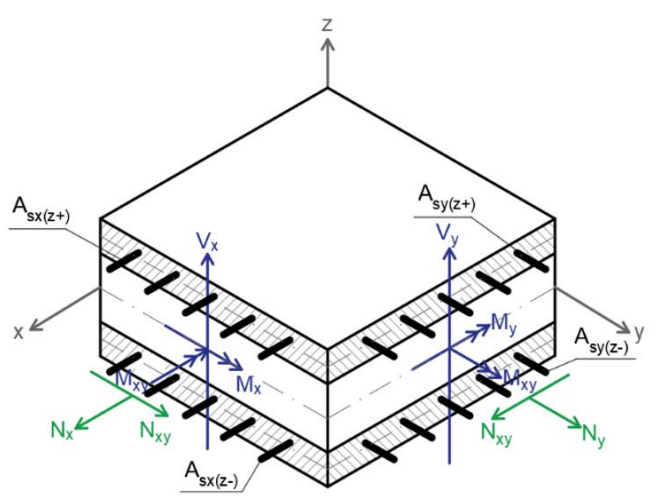

(a)

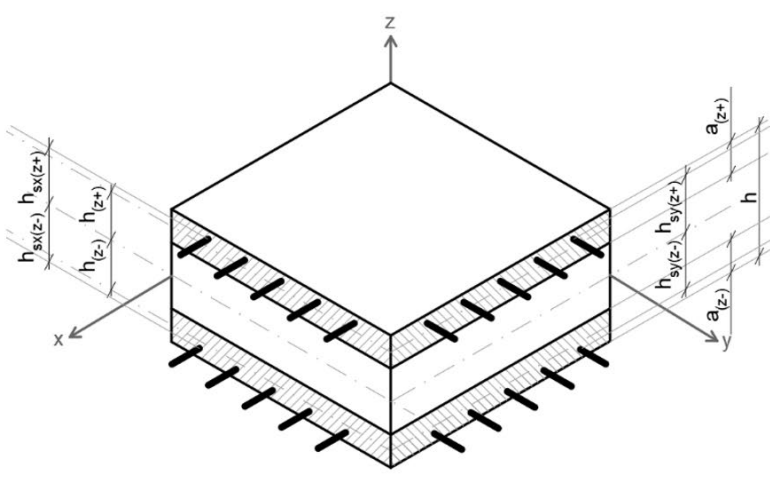

(b)

Figure 3. Reinforced concrete shell element idealized by the three-layer method. (a) Loads and reinforcement. (b) Dimensions.

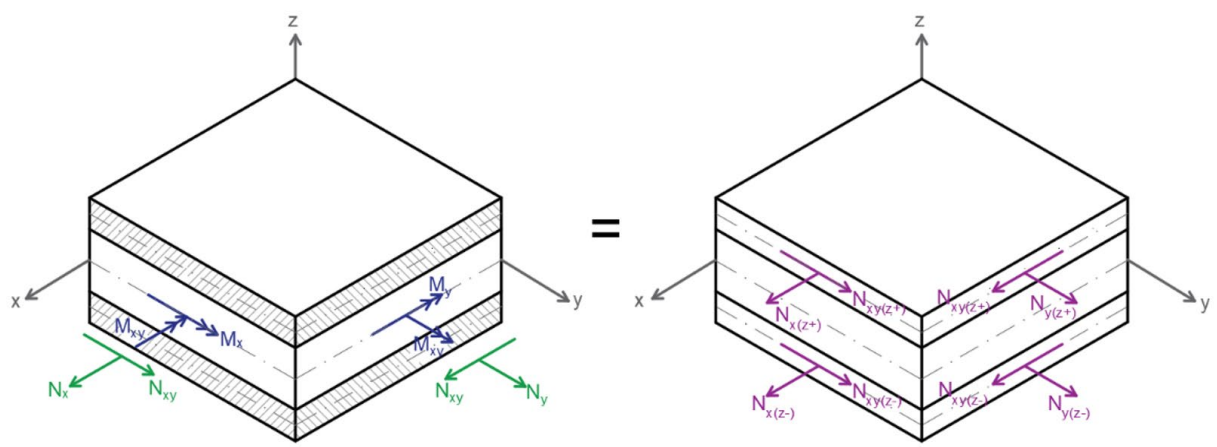

Figure 4. Equilibrium between the loads applied to the shell element and the membrane forces of the outer layers.

Note that in the equations resulting from the equilibrium the membrane forces in each outer layer are in the center of the respective layer. Thus, for the model to be valid, the reinforcement must also be in this position, which may not be true in practice. Then, it is necessary to correct the reinforcement and membrane forces to take into account the real position of the reinforcement in the element. For that, it is possible to impose the equilibrium between the forces in the reinforcement calculated in the center of the layers and the forces that occur in the real positions of the reinforcement. 
Such procedure, which is important in the iterative process of determining the reinforcement of shell elements, is illustrated in Figure 5a for the cases in which there is reinforcement in the two outer layers and in Figure $5 \mathrm{~b}$ for the cases in which the reinforcement is required only in one layer. Equations 7 and 8 calculate the real forces in the reinforcement when there is reinforcement in the two outer layers and Equations 9 to 12 calculate the real forces in the reinforcement when there is reinforcement in only one layer. $\mathrm{N}_{\mathrm{sx}, \mathrm{y}\left(\mathrm{z}^{+}\right)}$and $\mathrm{N}_{\mathrm{sx}, \mathrm{y}(\mathrm{z}-)}$ are resistance forces per unit length in the reinforcement $\mathrm{x}$ or $\mathrm{y}$ of the layers of faces $\mathrm{z}^{+}$and $\mathrm{z}-$, respectively, calculated in the center of the layers. $\mathrm{N}_{\mathrm{sx}, \mathrm{y}\left(\mathrm{z}^{+}\right) \text {shell }}$ and $\mathrm{N}_{\mathrm{sx}, \mathrm{y}(\mathrm{z}-\text { )shell }}$ are resistance forces per unit length in the reinforcement $\mathrm{x}$ or $\mathrm{y}$ of the layers of faces $\mathrm{z}^{+}$and $\mathrm{z}-$, respectively, calculated in the real position of the reinforcement. $\Delta \mathrm{N}_{\mathrm{x}, \mathrm{y}\left(\mathrm{z}^{+}\right)}$and $\Delta \mathrm{N}_{\mathrm{x}, \mathrm{y}(\mathrm{z}-)}$ are correction forces per unit length in the layers of faces $\mathrm{z}^{+}$and $\mathrm{z}-$, respectively.

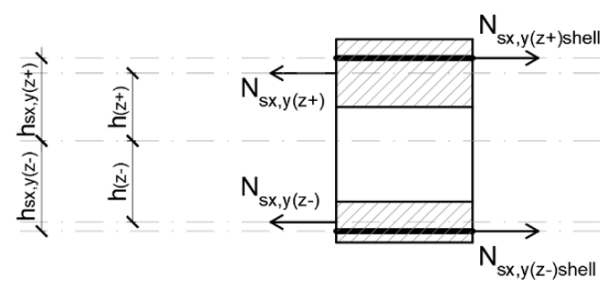

(a)

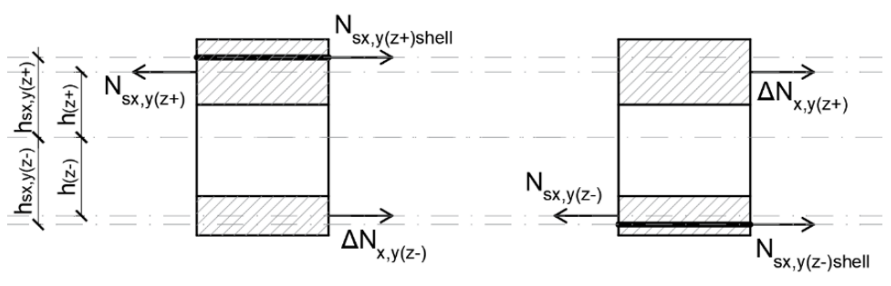

(b)

Figure 5. Correction of the forces in the reinforcement for cases in which the reinforcement is necessary in: (a) both outer layers.

(b) only one outer layer.

$\Sigma M_{\text {reinf. } .-}=0 \rightarrow N_{s x, y(z+)) \text { shell }}=\frac{N_{s x, y(z+)}\left(h_{(z+)}+h_{s x, y(z-)}\right)+N_{s x, y(z-)}\left(h_{s x, y(z-)}-h_{(z-)}\right)}{\left(h_{s x, y(z+)}+h_{s x, y(z-)}\right)}$

$N_{s x, y(z-) \text { shell }}=N_{s x, y(z+)}+N_{s x, y(z-)}-N_{s x, y(z+) \text { shell }}$

$\Sigma M_{\text {center of the layer of face z- }}=0 \rightarrow N_{s x, y(z+) \text { shell }}=\frac{N_{s x, y(z+)}\left(h_{(z+)}+h_{(z-)}\right)}{\left(h_{s x, y(z+)}+h_{(z-)}\right)}$

$\Delta N_{x, y(z-)}=N_{s x, y(z+)}-N_{s x, y(z+) s h e l l}$

$\Sigma M_{\text {center of the layer offace } z+}=0 \rightarrow N_{s x, y(z-) \text { shell }}=\frac{N_{s x, y(z-)}\left(h_{(z+)}+h_{(z-)}\right)}{\left(h_{s x, y(z-)}+h_{(z+)}\right)}$

$\Delta N_{x, y(z+)}=N_{s x, y(z-)}-N_{s x, y(z-) s h e l l}$

Once the membrane forces in each outer layer are found, the problem is to determine the reinforcement in each of such layers. The determination of the reinforcement in membrane elements has been studied by many authors, including Brandurn-Nielsen [7], Baumann [15] and Gupta [16]. The ideas present in Comité Euro-International du Betón [10] are based on the study of such authors. Consider the membrane element illustrated in Figure 6a. The membrane forces per unit length of the element must be equilibrated by the tensile forces per unit length in the reinforcement $\left(\mathrm{N}_{\mathrm{sx}}\right.$ and $\left.\mathrm{N}_{\mathrm{sy}}\right)$ and by the compressive force per unit length in the concrete in the direction of the cracks $\left(\mathrm{N}_{\mathrm{c}}\right)$. The angle $\theta$ is that between the $\mathrm{x}$-direction and the principal tensile direction (direction perpendicular to the cracks). The direction of the cracks is coincident with the principal compressive direction, because it is considered that there is no shear stress between the cracks. In addition, some other basic assumptions are made [15]: the cracks are approximately straight and parallel; the concrete tensile strength, the reinforcement dowel action, the aggregate interlock and the tension stiffening 
are neglected; perfect bonding is assumed between the concrete and the steel; the directions of principal stresses and principal strains are coincident.

Consider two sections of the membrane element shown in Figure 6a: one parallel to the crack (Figure 6b) and another perpendicular to the crack (Figure 6c), both of unit length. By imposing equilibrium between the membrane forces and the forces in the reinforcement and in the concrete and by applying the principle of the minimum resistance, Equations 13 and 14 are obtained on the basis of Figure $6 \mathrm{~b}$ and Equation 15 is obtained on the basis of Figure 6c.

$\Sigma F_{x}=0 \rightarrow N_{s x}=N_{x}+N_{x y} \operatorname{tg} \theta$

$\Sigma F_{y}=0 \rightarrow N_{s y}=N_{y}+N_{x y} \operatorname{cotg} \theta$

$\Sigma F_{x}=0 \rightarrow N_{c}=-\frac{N_{x y}}{\sin \theta \cos \theta}$

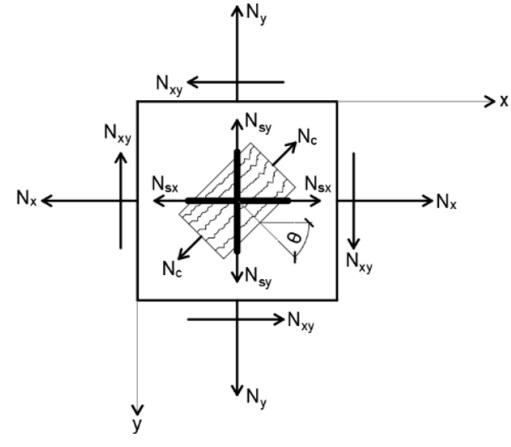

(a)

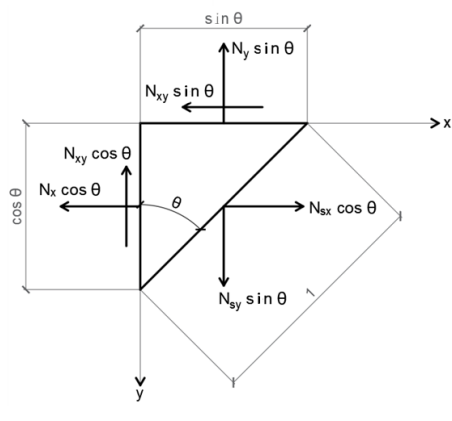

(b)

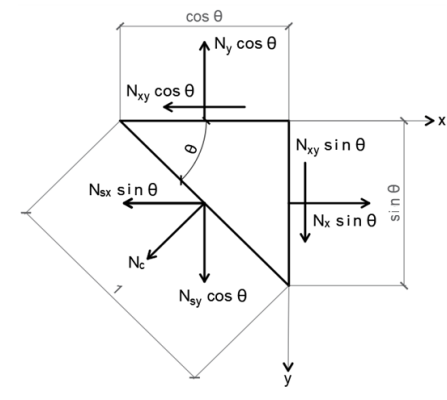

(c)

Figure 6. Membrane element. a) Membrane forces per unit length. b) Section parallel to the crack. c) Section perpendicular to the crack.

It is possible to see that there are three equations for four unknowns. Thus, if one variable were arbitrated, the other three could be determined. In the case in which the reinforcement is necessary in both directions, called case I in Comité Euro-International du Betón [10], the value of $\theta$ that provides the smallest reinforcement amount and, therefore, the most economical solution is $45^{\circ}$. For the case I, Equations 13 to 15 can be rewritten in the form of Equations 16 to 18 .

$$
N_{s x}=N_{x}+\left|N_{x y}\right|
$$

$N_{s y}=N_{y}+\left|N_{x y}\right|$

$N_{c}=-2\left|N_{x y}\right|$

When $\mathrm{N}_{\mathrm{sx}}$ is negative, there is no need for reinforcement in the $\mathrm{x}$-direction, leading to the called case II in Comité Euro-International du Betón [10]. Assuming $\mathrm{N}_{\mathrm{sx}}=0$, Equations 19 to 21 are obtained. 
$\operatorname{tg} \theta=-\frac{N_{x}}{N_{x y}}$

$N_{s y}=N_{y}-\frac{N_{x y}^{2}}{N_{x}}$

$N_{c}=N_{x}+\frac{N_{x y}^{2}}{N_{x}}$

Similarly, when $\mathrm{N}_{\mathrm{sy}}$ is negative, there is no need for reinforcement in the $\mathrm{y}$-direction, leading to the called case III in Comité Euro-International du Betón [10]. Assuming $\mathrm{N}_{\mathrm{sy}}=0$, Equations 22 to 24 are obtained.

$\operatorname{tg} \theta=-\frac{N_{x y}}{N_{y}}$

$N_{s x}=N_{x}-\frac{N_{x y}{ }^{2}}{N_{y}}$

$N_{c}=N_{y}+\frac{N_{x y}^{2}}{N_{y}}$

If Equations 20 and 23 also give negative values for $\mathrm{N}_{\mathrm{sy}}$ and $\mathrm{N}_{\mathrm{sx}}$, respectively, no reinforcement is necessary in the membrane, leading to the called case IV in Comité Euro-International du Betón [10]. The value of $\mathrm{N}_{\mathrm{c}}$ is the value of the minimum principal force $\mathrm{N}_{\mathrm{c} 2}$. The maximum principal force $\mathrm{N}_{\mathrm{c} 1}$ must also be compressive. The principal forces are obtained by Equations 25 and 26.

$N_{c l}=\frac{N_{x}+N_{y}}{2}+\sqrt{\left(\frac{N_{x}-N_{y}}{2}\right)^{2}+N_{x y}{ }^{2}}$

$N_{c 2}=\frac{N_{x}+N_{y}}{2}-\sqrt{\left(\frac{N_{x}-N_{y}}{2}\right)^{2}+N_{x y}{ }^{2}}$

Once the forces in the reinforcement are obtained, the required area of reinforcement per unit length can be determined by Equations 27 and 28 for $\mathrm{x}$-direction and y-direction, respectively, imposing the yield stress on the reinforcement.

$A_{s x}=\frac{N_{s x}}{f_{y d}}$

$A_{s y}=\frac{N_{s y}}{f_{y d}}$

In the design process of reinforced concrete shell elements, the thickness of the layer required to resist $\mathrm{N}_{\mathrm{c}}$ must be determined by Equation 29. 
$a=\frac{N_{c}}{f_{c}}$

One possibility for determining $\mathrm{f}_{\mathrm{c}}$ in each outer layer is to consider an uniform compressive strength of the concrete depending on the cracking state to which the concrete is subjected. According to Comite Euro-International du Betón [10], when the concrete is uncracked, $\mathrm{f}_{\mathrm{c}}$ can be given by Equation 30. If the concrete is cracked, $\mathrm{f}_{\mathrm{c}}$ can be given by Equation 31 .

$$
\begin{aligned}
& f_{c}=f_{c d 1}=0.85\left(1-\frac{f_{c k}}{250}\right) f_{c d} \\
& f_{c}=f_{c d 2}=0.60\left(1-\frac{f_{c k}}{250}\right) f_{c d}
\end{aligned}
$$

Colombo et al. [12] propose a model for the concrete that is based on the experimental results obtained by Vecchio and Collins [17]. Such model assumes that the maximum compressive strength $\mathrm{f}_{\mathrm{cmax}}$ of the concrete decreases as the maximum tensile strain $\varepsilon_{1}$ increases. This property can be described by Equation 32, which depends on $\mathrm{f}_{\mathrm{ck}}$ and on the shortening strain $\varepsilon_{\mathrm{cp}}$ corresponding to the concrete strength peak.

$$
f_{c \max }=\frac{f_{c k}}{0.8-0.34\left(\varepsilon_{1} / \varepsilon_{c p}\right)}
$$

Colombo et al. [12] consider that for cases I, II and III, in which the concrete is cracked, $\mathrm{f}_{\mathrm{c}}$ can be interpolated between the values of $f_{c d 1}$ and $f_{c d 2}$ through Equation 33. For the case IV, Equation 30 is valid because the concrete is uncracked. In this case, one can further increase the strength of the concrete by a factor $\mathrm{K}$ due to the existing biaxial compression. Such factor depends on the principal stresses $\sigma_{1}$ and $\sigma_{2}$ and is given by Equation 34 .

$$
\begin{aligned}
& f_{c}=\frac{f_{c d l}}{0.8-0.34\left(\varepsilon_{1} / \varepsilon_{c p}\right)}, \text { where } \frac{0.6}{0.85} \leq \frac{1}{0.8-0.34\left(\varepsilon_{1} / \varepsilon_{c p}\right)} \leq 1 \\
& K=\frac{1+3.8\left(\sigma_{1} / \sigma_{2}\right)}{\left(1+\sigma_{1} / \sigma_{2}\right)^{2}}
\end{aligned}
$$

The use of Equation 33 depends on the determination of $\varepsilon_{1}$, which can be done by using Equations 35 and 36 proposed by Gupta [16]. For the case I, the strain $\varepsilon_{1}$ can be determined by assuming $\varepsilon_{2}$ equal to $\varepsilon_{\mathrm{cp}}, \varepsilon_{\mathrm{x}}$ equal to the steel yield strain $\varepsilon_{\mathrm{yi}}$ and $\theta=45^{\circ}$. Equation 37 can be used for case I. For case II, it is assumed that $\varepsilon_{2}$ is equal to $\varepsilon_{\mathrm{cp}}$ and $\varepsilon_{\mathrm{y}}$ is equal to $\varepsilon_{\mathrm{y}}$, leading to Equation 38. For case III, in its turn, it is assumed that $\varepsilon_{2}$ is equal to $\varepsilon_{\mathrm{cp}}$ and $\varepsilon_{\mathrm{x}}$ is equal to $\varepsilon_{\mathrm{yi}}$, leading to Equation 39.

$\varepsilon_{x}=\varepsilon_{1} \cos ^{2} \theta+\varepsilon_{2} \sin ^{2} \theta$

$\varepsilon_{y}=\varepsilon_{1} \sin ^{2} \theta+\varepsilon_{2} \cos ^{2} \theta$

$\varepsilon_{1}=2\left(\varepsilon_{y i}-0.5 \varepsilon_{c p}\right)$ 
$\varepsilon_{1}=\frac{\left(\varepsilon_{y i}-\varepsilon_{c p} \cos ^{2} \theta\right)}{\sin ^{2} \theta}$

$\varepsilon_{l}=\frac{\left(\varepsilon_{y i}-\varepsilon_{c p} \sin ^{2} \theta\right)}{\cos ^{2} \theta}$

From the design expressions for membrane elements, the iterative procedure proposed by Colombo et al. [12] can be used to estimate the reinforcement of the reinforced concrete shell element. For that, the thicknesses $\mathrm{a}_{\left.\mathrm{z}^{+}\right)}$and $\mathrm{a}_{(\mathrm{z}-)}$ of the outer layers of the idealized shell element are arbitrated. Then, the membrane forces in each of the outer layers are estimated and their design are done. The initial values of the forces in the reinforcement are corrected taking into account the difference between the centers of the layers and the real positions of the reinforcement. With the values of $\mathrm{N}_{\mathrm{c}\left(\mathrm{z}^{+}\right)}$and $\mathrm{N}_{\mathrm{c}(\mathrm{z}-)}$, new values of $\mathrm{a}_{\left(\mathrm{z}^{+}\right)}$and $\mathrm{a}_{(\mathrm{z}-)}$ are obtained. The procedure is repeated until the thicknesses converge. According to Colombo et al. [12], the mentioned iterative process presents a good convergence and stability since Equation 33 introduces a certain continuity to the behavior of the concrete under compression, that is, there is a gradual transition between the non-cracked state of the concrete and the totally cracked state of the concrete.

\subsection{Numerical examples}

To illustrate the iterative procedure proposed by Colombo et al. [12], four numerical examples of shell elements are presented below. Table 1 presents the geometry and material data as well as the loads to which such elements are subjected. The elements can, for example, be taken from a linear finite element analysis carried out for the bottom discharge of the dam illustrated in Figure 2.

Table 1. Shell element data.

\begin{tabular}{cccccccccccccccc}
\hline Elem. & $\begin{array}{c}\mathbf{h} \\
{[\mathbf{m}]}\end{array}$ & $\begin{array}{c}\mathbf{h}_{\mathbf{s x}(\mathbf{z}+)} \\
{[\mathbf{m}]}\end{array}$ & $\begin{array}{c}\mathbf{h}_{\mathbf{s x}(\mathbf{z}-)} \\
{[\mathbf{m}]}\end{array}$ & $\begin{array}{c}\mathbf{h}_{\mathbf{s y}(\mathbf{z}+)} \\
{[\mathbf{m}]}\end{array}$ & $\begin{array}{c}\mathbf{h}_{\mathbf{s y}(\mathbf{z}-)} \\
{[\mathbf{m}]}\end{array}$ & $\begin{array}{c}\mathbf{f}_{\mathbf{c k}} \\
{[\mathbf{M P a}]}\end{array}$ & $\begin{array}{c}\mathbf{f}_{\mathbf{y k}} \\
{[\mathbf{M P a}]}\end{array}$ & $\boldsymbol{\gamma}_{\mathbf{c}}$ & $\gamma_{\mathbf{s}}$ & $\begin{array}{c}\mathbf{N}_{\mathbf{x}} \\
{[\mathbf{t f} / \mathbf{m}]}\end{array}$ & $\begin{array}{c}\mathbf{N}_{\mathbf{y}} \\
{[\mathbf{t f} / \mathbf{m}]}\end{array}$ & $\begin{array}{c}\mathbf{N}_{\mathbf{x y}} \\
{[\mathbf{t f} / \mathbf{m}]}\end{array}$ & $\begin{array}{c}\mathbf{M}_{\mathbf{x}} \\
{[\mathbf{t f . m} / \mathbf{m}]}\end{array}$ & $\begin{array}{c}\mathbf{M}_{\mathbf{y}} \\
{[\mathbf{t f .} \mathbf{m} / \mathbf{m}]}\end{array}$ & $\begin{array}{c}\mathbf{M}_{\mathbf{x y}} \\
{[\mathbf{t f} . \mathbf{m} / \mathbf{m}]}\end{array}$ \\
\hline 1 & 1.5 & 0.55 & 0.477 & 0.55 & 0.477 & 20 & 500 & 1.4 & 1.15 & 202.46 & -9.31 & 27.26 & -28.79 & -36.28 & -16.66 \\
2 & 1.5 & 0.55 & 0.477 & 0.55 & 0.477 & 20 & 500 & 1.4 & 1.15 & -4.72 & 124.82 & -10.59 & -0.38 & 23.24 & 4.82 \\
3 & 1.5 & 0.55 & 0.477 & 0.55 & 0.477 & 20 & 500 & 1.4 & 1.15 & -175.95 & -544.86 & -93.69 & 50.40 & 303.93 & 19.62 \\
4 & 1.5 & 0.55 & 0.477 & 0.55 & 0.477 & 20 & 500 & 1.4 & 1.15 & -161.52 & 733.60 & -65.28 & 201.20 & 968.00 & 94.40 \\
\hline
\end{tabular}

The first step in the process of determining the reinforcement of a shell element is to estimate the thicknesses $\mathrm{a}_{\left(\mathrm{z}^{+}\right)}$and $\mathrm{a}_{(\mathrm{z}-)}$ of the upper and lower layers of the idealized element and to determine $\mathrm{h}_{\left(\mathrm{z}^{+}\right)}$and $\mathrm{h}_{(\mathrm{z}-\mathrm{-})}$. Colombo et al. [12] propose as an initial thickness estimate the value of 0.2 times the total thickness of the element. See Equations 40 and 41.

$a_{(z+)}=a_{(z-)}=0.2 \times 1.50=0.30 \mathrm{~m}$

$h_{(z+)}=h_{(z-)}=\frac{1.50}{2}-\frac{0.30}{2}=0.60 \mathrm{~m}$

Next, the values of the membrane forces acting on the upper and lower layers must be estimated by using Equations 1 to 6 . Table 2 presents the membrane forces for the upper layers of the four shell elements and Table 3 presents the membrane forces for the lower layers of the four shell elements.

With the membrane forces, it is possible to estimate the principal forces acting on each layer. Table 4 presents such forces for the upper layers and Table 5 presents such forces for the lower layers of the four shell elements.

It is possible to note that for the lower layers of the elements 3 and 4 the values of $\mathrm{N}_{\mathrm{c} 1}$ are negative; therefore, no reinforcement in the $\mathrm{x}$-direction and $\mathrm{y}$-direction will be required. This is the case of designing IV. For the lower layers of the elements 1 and 2 and for the upper layer of the element $4, \mathrm{~N}_{\mathrm{x}\left(\mathrm{z}^{+}\right) /\left(\mathrm{z}_{-}\right)}>-\left|\mathrm{N}_{\mathrm{xy}\left(\mathrm{z}^{+}\right) /(\mathrm{z}-)}\right|$ and $\mathrm{N}_{\mathrm{y}\left(\mathrm{z}^{+}\right) /(\mathrm{z}-)}>-$ 
$\left|\mathrm{N}_{\mathrm{xy}(\mathrm{z}+) /(\mathrm{z}-)}\right|$. Thus, there will be reinforcement in the $\mathrm{x}$-direction and $\mathrm{y}$-direction, leading to the case of designing I. For the upper layer of the element $1, \mathrm{~N}_{\mathrm{x}\left(\mathrm{z}^{+}\right)}>-\left|\mathrm{N}_{\mathrm{xy}\left(\mathrm{z}^{+}\right)}\right|$and $\mathrm{N}_{\mathrm{y}\left(\mathrm{z}^{+}\right)}<-\left|\mathrm{N}_{\mathrm{xy}\left(\mathrm{z}^{+}\right)}\right|$, which leads to the case of designing III. Finally, the upper layers of the elements 2 and 3 have $\mathrm{N}_{\mathrm{x}\left(\mathrm{z}^{+}\right)}<-\left|\mathrm{N}_{\mathrm{xy}\left(\mathrm{z}^{+}\right)}\right|$and $\mathrm{N}_{\mathrm{y}\left(\mathrm{z}^{+}\right)}>-\left|\mathrm{N}_{\mathrm{xy}\left(\mathrm{z}^{+}\right)}\right|$, which leads to the case of designing II. The design of the upper and lower layers are presented in Table 6 and Table 7, respectively, for the four shell elements.

Since the formulation assumes that the reinforcement is in the center of the outer layers, the forces in the reinforcement and the membrane forces must be corrected to take into account the real position of the reinforcement in the element. Table 8 presents the results of this correction in the $\mathrm{x}$-direction and $\mathrm{y}$-direction for the shell elements 1 and 2 . Table 9, in its turn, presents the results of the correction in the $\mathrm{x}$-direction and y-direction for the shell elements 3 and 4 .

Table 2. Membrane forces for the upper layers.

\begin{tabular}{ccc}
\hline \multicolumn{3}{c}{ Element 1 } \\
\hline \multicolumn{2}{c}{ Membrane forces } & Equation \\
\hline $\mathrm{N}_{\mathrm{x}\left(\mathrm{z}^{+}\right)}[\mathrm{tf} / \mathrm{m}]$ & 77.24 & $(1)$ \\
$\mathrm{N}_{\mathrm{y}(\mathrm{z})}[\mathrm{tf} / \mathrm{m}]$ & -34.89 & $(2)$ \\
$\mathrm{N}_{\mathrm{xy}(\mathrm{z}+)}[\mathrm{tf} / \mathrm{m}]$ & -0.25 & $(3)$ \\
\hline \multicolumn{3}{c}{ Element 2 } \\
\hline \multicolumn{4}{c}{ Membrane forces } & Equation \\
\hline $\mathrm{N}_{\mathrm{x}\left(\mathrm{z}^{+}\right)}[\mathrm{tf} / \mathrm{m}]$ & -2.68 & $(1)$ \\
$\mathrm{N}_{\mathrm{y}\left(\mathrm{z}^{+}\right)}[\mathrm{tf} / \mathrm{m}]$ & 81.78 & $(2)$ \\
$\mathrm{N}_{\mathrm{xy}(\mathrm{z}+}[\mathrm{tf} / \mathrm{m}]$ & -1.28 & $(3)$ \\
\hline
\end{tabular}

\begin{tabular}{ccc}
\hline \multicolumn{3}{c}{ Element 3 } \\
\hline \multicolumn{2}{c}{ Membrane forces } & Equation \\
\hline $\mathrm{N}_{\mathrm{x}\left(\mathrm{z}^{+}\right)}[\mathrm{tf} / \mathrm{m}]$ & -45.98 & $(1)$ \\
$\mathrm{N}_{\mathrm{y}\left(\mathrm{z}^{+}\right)}[\mathrm{tf} / \mathrm{m}]$ & -19.15 & $(2)$ \\
$\mathrm{N}_{\mathrm{xy}\left(\mathrm{z}^{+}\right)}[\mathrm{tf} / \mathrm{m}]$ & -30.50 & $(3)$ \\
\hline \multicolumn{3}{c}{ Element 4 } \\
\hline \multicolumn{2}{c}{ Membrane forces } & Equation \\
\hline $\mathrm{N}_{\mathrm{x}\left(\mathrm{z}^{+}\right)}[\mathrm{tf} / \mathrm{m}]$ & 86.91 & $(1)$ \\
$\mathrm{N}_{\mathrm{y}\left(\mathrm{z}^{+}\right)}[\mathrm{tf} / \mathrm{m}]$ & 1173.47 & $(2)$ \\
$\mathrm{N}_{\mathrm{xy}\left(\mathrm{z}^{+}\right)}[\mathrm{tf} / \mathrm{m}]$ & 46.03 & $(3)$ \\
\hline
\end{tabular}

Table 3. Membrane forces for the lower layers.

\begin{tabular}{ccc}
\hline \multicolumn{3}{c}{ Element 1} \\
\hline \multicolumn{2}{c}{ Membrane forces } & Equation \\
\hline $\mathrm{N}_{\mathrm{x}(\mathrm{z}-)}[\mathrm{tf} / \mathrm{m}]$ & 125.22 & $(4)$ \\
$\mathrm{N}_{\mathrm{y}(\mathrm{z})}[\mathrm{tf} / \mathrm{m}]$ & 25.58 & $(5)$ \\
$\mathrm{N}_{\mathrm{xy}(\mathrm{z})}[\mathrm{tf} / \mathrm{m}]$ & 27.51 & $(6)$ \\
\hline \multicolumn{4}{c}{ Element 2} \\
\hline \multicolumn{4}{c}{ Membrane forces } & Equation \\
\hline $\mathrm{N}_{\mathrm{x}(\mathrm{z})}[\mathrm{tf} / \mathrm{m}]$ & -2.04 & $(4)$ \\
$\mathrm{N}_{\mathrm{y}(\mathrm{z}-)}[\mathrm{tf} / \mathrm{m}]$ & 43.04 & $(5)$ \\
$\mathrm{N}_{\mathrm{xy}(\mathrm{z}-)}[\mathrm{tf} / \mathrm{m}]$ & -9.31 & $(6)$ \\
\hline
\end{tabular}

\begin{tabular}{ccc}
\hline \multicolumn{3}{c}{ Element 3 } \\
\hline \multicolumn{2}{c}{ Membrane forces } & Equation \\
\hline $\mathrm{N}_{\mathrm{x}(\mathrm{z}-)}[\mathrm{tf} / \mathrm{m}]$ & -129.98 & $(4)$ \\
$\mathrm{N}_{\mathrm{y}(\mathrm{z}-\mathrm{m})}[\mathrm{tf} / \mathrm{m}]$ & -525.71 & $(5)$ \\
$\mathrm{N}_{\mathrm{xy}(\mathrm{z}-)}[\mathrm{tf} / \mathrm{m}]$ & -63.20 & $(6)$ \\
\hline \multicolumn{3}{c}{ Element 4 } \\
\hline \multicolumn{4}{c}{ Membrane forces } & Equation \\
\hline $\mathrm{N}_{\mathrm{x}(\mathrm{z}-)}[\mathrm{tf} / \mathrm{m}]$ & -248.43 & $(4)$ \\
$\mathrm{N}_{\mathrm{y}(\mathrm{z})}[\mathrm{tf} / \mathrm{m}]$ & -439.87 & $(5)$ \\
$\mathrm{N}_{\mathrm{xy}(\mathrm{z}-)}[\mathrm{tf} / \mathrm{m}]$ & -111.31 & $(6)$ \\
\hline
\end{tabular}

Table 4. Principal forces for the upper layers.

\begin{tabular}{|c|c|c|}
\hline \multicolumn{3}{|c|}{ Element 1} \\
\hline \multicolumn{3}{|c|}{ Case of designing III } \\
\hline \multicolumn{2}{|c|}{ Principal forces } & Equation \\
\hline $\mathrm{N}_{\mathrm{cl}\left(\mathrm{z}^{+}\right)}[\mathrm{tf} / \mathrm{m}]$ & 77.24 & (25) \\
\hline $\mathrm{N}_{\mathrm{c} 2\left(\mathrm{z}^{+}\right)}[\mathrm{tf} / \mathrm{m}]$ & -34.89 & (26) \\
\hline \multicolumn{3}{|c|}{ Element 2} \\
\hline \multicolumn{3}{|c|}{ Case of designing II } \\
\hline \multicolumn{2}{|c|}{ Principal forces } & Equation \\
\hline $\mathrm{N}_{\mathrm{cl}\left(\mathrm{z}^{+}\right)}[\mathrm{tf} / \mathrm{m}]$ & 81.80 & (25) \\
\hline $\mathrm{N}_{\mathrm{c} 2\left(\mathrm{z}^{+}\right)}[\mathrm{tf} / \mathrm{m}]$ & -2.70 & (26) \\
\hline
\end{tabular}

\begin{tabular}{|c|c|c|}
\hline \multicolumn{3}{|c|}{ Element 3} \\
\hline \multicolumn{3}{|c|}{ Case of designing II } \\
\hline \multicolumn{2}{|c|}{ Principal forces } & Equation \\
\hline $\mathrm{N}_{\mathrm{cl}(\mathrm{z}+)}[\mathrm{tf} / \mathrm{m}]$ & 0.75 & (25) \\
\hline $\mathrm{N}_{\mathrm{c} 2\left(\mathrm{z}^{+}\right)}[\mathrm{tf} / \mathrm{m}]$ & -65.88 & (26) \\
\hline \multicolumn{3}{|c|}{ Element 4} \\
\hline \multicolumn{3}{|c|}{ Case of designing I } \\
\hline \multicolumn{2}{|c|}{ Principal forces } & Equation \\
\hline $\mathrm{N}_{\mathrm{cl}(\mathrm{z}+)}[\mathrm{tf} / \mathrm{m}]$ & 1175.41 & (25) \\
\hline $\mathrm{N}_{\mathrm{c} 2(\mathrm{z}+)}[\mathrm{tf} / \mathrm{m}]$ & 84.96 & (26) \\
\hline
\end{tabular}


Table 5. Principal forces for the lower layers.

\begin{tabular}{|c|c|c|}
\hline \multicolumn{3}{|c|}{ Element 1} \\
\hline \multicolumn{3}{|c|}{ Case of designing I } \\
\hline \multicolumn{2}{|c|}{ Principal forces } & Equation \\
\hline $\mathrm{N}_{\mathrm{cl}(\mathrm{z}-)}[\mathrm{tf} / \mathrm{m}]$ & 132.31 & $(25)$ \\
\hline $\mathrm{N}_{\mathrm{c} 2(\mathrm{z}-)}[\mathrm{tf} / \mathrm{m}]$ & 18.49 & (26) \\
\hline \multicolumn{3}{|c|}{ Element 2} \\
\hline \multicolumn{3}{|c|}{ Case of designing $I$} \\
\hline \multicolumn{2}{|c|}{ Principal forces } & Equation \\
\hline $\mathrm{N}_{\mathrm{cl}(\mathrm{z}-)}[\mathrm{tf} / \mathrm{m}]$ & 44.89 & $(25)$ \\
\hline $\mathrm{N}_{\mathrm{c} 2(\mathrm{z}-)}[\mathrm{tf} / \mathrm{m}]$ & -3.89 & (26) \\
\hline
\end{tabular}

\begin{tabular}{|c|c|c|}
\hline \multicolumn{3}{|c|}{ Element 3} \\
\hline \multicolumn{3}{|c|}{ Case of designing IV } \\
\hline \multicolumn{2}{|c|}{ Principal forces } & Equation \\
\hline $\mathrm{N}_{\mathrm{cl}(\mathrm{z}-)}[\mathrm{tf} / \mathrm{m}]$ & -120.13 & $(25)$ \\
\hline $\mathrm{N}_{\mathrm{c} 2(\mathrm{z}-)}[\mathrm{tf} / \mathrm{m}]$ & -535.55 & $(26)$ \\
\hline \multicolumn{3}{|c|}{ Element 4} \\
\hline \multicolumn{3}{|c|}{ Case of designing IV } \\
\hline \multicolumn{2}{|c|}{ Principal forces } & Equation \\
\hline $\mathrm{N}_{\mathrm{c} 1(\mathrm{z}-)}[\mathrm{tf} / \mathrm{m}]$ & -197.34 & $(25)$ \\
\hline $\mathrm{N}_{\mathrm{c} 2(\mathrm{z}-)}[\mathrm{tf} / \mathrm{m}]$ & -490.95 & (26) \\
\hline
\end{tabular}

Table 6. Design of the upper layers.

\begin{tabular}{|c|c|c|}
\hline \multicolumn{3}{|c|}{ Element 1} \\
\hline \multicolumn{3}{|c|}{ Case of designing III } \\
\hline \multicolumn{2}{|c|}{ Design parameters } & Equation \\
\hline $\mathrm{Ns}_{\mathrm{x}}(\mathrm{z}+)[\mathrm{tf} / \mathrm{m}]$ & 77.24 & (23) \\
\hline $\mathrm{Ns}_{\mathrm{y}(\mathrm{z}+)}[\mathrm{tf} / \mathrm{m}]$ & 0.00 & - \\
\hline $\mathrm{N}_{\mathrm{c}(\mathrm{z}+)}[\mathrm{tf} / \mathrm{m}]$ & -34.89 & (24) \\
\hline $\operatorname{tg} \theta$ & -0.01 & $(22)$ \\
\hline \multicolumn{3}{|c|}{ Element 2} \\
\hline \multicolumn{3}{|c|}{ Case of designing II } \\
\hline \multicolumn{2}{|c|}{ Design parameters } & Equation \\
\hline $\mathrm{Ns}_{\mathrm{x}(\mathrm{z}+)}[\mathrm{tf} / \mathrm{m}]$ & 0.00 & - \\
\hline $\mathrm{NSy}_{(\mathrm{z}+)}[\mathrm{tf} / \mathrm{m}]$ & 82.39 & $(20)$ \\
\hline $\mathrm{N}_{\mathrm{c}(\mathrm{z}+)}[\mathrm{tf} / \mathrm{m}]$ & -3.29 & $(21)$ \\
\hline $\operatorname{tg} \theta$ & -2.09 & (19) \\
\hline
\end{tabular}

\begin{tabular}{|c|c|c|}
\hline \multicolumn{3}{|c|}{ Element 3} \\
\hline \multicolumn{3}{|c|}{ Case of designing II } \\
\hline \multicolumn{2}{|c|}{ Design parameters } & Equation \\
\hline $\mathrm{NS}_{\mathrm{x}\left(\mathrm{z}^{+}\right)}[\mathrm{tf} / \mathrm{m}]$ & 0.00 & - \\
\hline $\mathrm{Nsy}_{\left(\mathrm{z}^{+}\right)}[\mathrm{tf} / \mathrm{m}]$ & 1.07 & (20) \\
\hline $\mathrm{N}_{\mathrm{c}(\mathrm{z}+)}[\mathrm{tf} / \mathrm{m}]$ & -66.20 & $(21)$ \\
\hline $\operatorname{tg} \theta$ & -1.51 & (19) \\
\hline \multicolumn{3}{|c|}{ Element 4} \\
\hline \multicolumn{3}{|c|}{ Case of designing I } \\
\hline \multicolumn{2}{|c|}{ Design parameters } & Equation \\
\hline $\mathrm{Ns}_{\mathrm{x}\left(\mathrm{z}^{+}\right)}[\mathrm{tf} / \mathrm{m}]$ & 132.93 & (16) \\
\hline $\mathrm{Nsy}\left(\mathrm{z}^{+}\right)[\mathrm{tf} / \mathrm{m}]$ & 1219.49 & (17) \\
\hline $\mathrm{N}_{\mathrm{c}(\mathrm{z}+)}[\mathrm{tf} / \mathrm{m}]$ & -92.05 & $(18)$ \\
\hline $\operatorname{tg} \theta$ & 1.00 & - \\
\hline
\end{tabular}

Table 7. Design of the lower layers.

\begin{tabular}{|c|c|c|}
\hline \multicolumn{3}{|c|}{ Element 1} \\
\hline \multicolumn{3}{|c|}{ Case of designing I } \\
\hline \multicolumn{2}{|c|}{ Design parameters } & Equation \\
\hline $\mathrm{Ns}_{\mathrm{x}(\mathrm{z}-)}[\mathrm{tf} / \mathrm{m}]$ & 152.74 & (16) \\
\hline $\mathrm{Nsy}_{(\mathrm{z})}[\mathrm{tf} / \mathrm{m}]$ & 53.09 & (17) \\
\hline $\mathrm{N}_{\mathrm{c}(\mathrm{z}-)}[\mathrm{tf} / \mathrm{m}]$ & -55.03 & (18) \\
\hline $\operatorname{tg} \theta$ & 1.00 & - \\
\hline \multicolumn{3}{|c|}{ Element 2} \\
\hline \multicolumn{3}{|c|}{ Case of designing I } \\
\hline \multicolumn{2}{|c|}{ Design parameters } & Equation \\
\hline $\mathrm{Ns}_{\mathrm{x}(\mathrm{z}-)}[\mathrm{tf} / \mathrm{m}]$ & 7.27 & $(16)$ \\
\hline $\mathrm{Nsy}_{(\mathrm{z}-)}[\mathrm{tf} / \mathrm{m}]$ & 52.36 & (17) \\
\hline $\mathrm{N}_{\mathrm{c}(\mathrm{z}-)}[\mathrm{tf} / \mathrm{m}]$ & -18.62 & (18) \\
\hline $\operatorname{tg} \theta$ & 1.00 & - \\
\hline
\end{tabular}

\begin{tabular}{|c|c|c|}
\hline \multicolumn{3}{|c|}{ Element 3} \\
\hline \multicolumn{3}{|c|}{ Case of designing IV } \\
\hline \multicolumn{2}{|c|}{ Design parameters } & Equation \\
\hline $\mathrm{Ns}_{\mathrm{x}(\mathrm{z}-)}[\mathrm{tf} / \mathrm{m}]$ & 0.00 & - \\
\hline $\mathrm{Nsy}_{(\mathrm{z}-)}[\mathrm{tf} / \mathrm{m}]$ & 0.00 & - \\
\hline $\mathrm{N}_{\mathrm{c}(\mathrm{z}-)}[\mathrm{tf} / \mathrm{m}]$ & -535.55 & (26) \\
\hline $\operatorname{tg} \theta$ & - & - \\
\hline \multicolumn{3}{|c|}{ Element 4} \\
\hline \multicolumn{3}{|c|}{ Case of designing IV } \\
\hline \multicolumn{2}{|c|}{ Design parameters } & Equation \\
\hline $\mathrm{Ns}_{\mathrm{x}(\mathrm{z}-)}[\mathrm{tf} / \mathrm{m}]$ & 0.00 & - \\
\hline $\mathrm{Ns}_{\mathrm{y}(\mathrm{z}-)}[\mathrm{tf} / \mathrm{m}]$ & 0.00 & - \\
\hline $\mathrm{N}_{\mathrm{c}(\mathrm{z}-)}[\mathrm{tf} / \mathrm{m}]$ & -490.95 & (26) \\
\hline $\operatorname{tg} \theta$ & - & - \\
\hline
\end{tabular}


Table 8. Correction of the position of the reinforcement in the x-direction and y-direction for elements 1 and 2.

\begin{tabular}{ccc}
\hline \multicolumn{3}{c}{ Element 1 - x-direction } \\
\hline \multicolumn{1}{c}{ Correction } & & Equation \\
\hline $\left.\mathrm{Nsx}_{\mathrm{x}} \mathrm{z}^{+}\right)$shell $[\mathrm{tf} / \mathrm{m}]$ & 62.71 & $(7)$ \\
$\mathrm{Ns}_{\mathrm{x}}(\mathrm{z}-)$ shell $[\mathrm{tf} / \mathrm{m}]$ & 167.27 & $(8)$ \\
\hline
\end{tabular}

\begin{tabular}{ccc}
\hline \multicolumn{3}{c}{ Element 2 - x-direction } \\
\hline \multicolumn{1}{c}{ Correction } & Equation \\
\hline $\mathrm{Nsx}_{\mathrm{x}(\mathrm{z}) \text { shell }}[\mathrm{tf} / \mathrm{m}]$ & 8.10 & $(11)$ \\
$\Delta \mathrm{N}_{\mathrm{x}(\mathrm{z}+)}[\mathrm{tf} / \mathrm{m}]$ & -0.83 & $(12)$ \\
$\mathrm{N}_{\mathrm{x}(\mathrm{z}+}[\mathrm{tf} / \mathrm{m}]$ & -3.51 & - \\
$\mathrm{N}_{\mathrm{y}\left(\mathrm{z}^{+}\right)}[\mathrm{tf} / \mathrm{m}]$ & 81.78 & - \\
$\mathrm{N}_{\mathrm{xy}\left(\mathrm{z}^{+}\right)}[\mathrm{tf} / \mathrm{m}]$ & -1.28 & - \\
$\mathrm{N}_{\mathrm{c} 1(\mathrm{z}+}[\mathrm{tf} / \mathrm{m}]$ & 81.80 & $(25)$ \\
$\mathrm{N}_{\mathrm{c} 2(\mathrm{z}+}[\mathrm{tf} / \mathrm{m}]$ & -3.53 & $(26)$ \\
$\mathrm{Ns}_{\mathrm{x}(\mathrm{z}+)}[\mathrm{tf} / \mathrm{m}]$ & 0.00 & - \\
$\mathrm{Ns}_{\mathrm{y}(\mathrm{z}+)}[\mathrm{tf} / \mathrm{m}]$ & 82.24 & $(20)$ \\
$\mathrm{N}_{\mathrm{c}(\mathrm{z}+)}[\mathrm{tf} / \mathrm{m}]$ & -3.97 & $(21)$ \\
$\operatorname{tg} \theta$ & -2.74 & $(19)$ \\
\hline
\end{tabular}

\begin{tabular}{ccc}
\hline \multicolumn{3}{c}{ Element 1 - y-direction } \\
\hline \multicolumn{1}{c}{ Correction } & Equation \\
\hline $\mathrm{Ns}_{\mathrm{y}(\mathrm{z}-) \text { shell }[\mathrm{tf} / \mathrm{m}]}$ & 59.16 & $(11)$ \\
$\Delta \mathrm{N}_{\mathrm{y}\left(\mathrm{z}^{+}\right)}[\mathrm{tf} / \mathrm{m}]$ & -6.06 & $(12)$ \\
$\mathrm{N}_{\mathrm{x}\left(\mathrm{z}^{+}\right)}[\mathrm{tf} / \mathrm{m}]$ & 77.24 & - \\
$\mathrm{N}_{\mathrm{y}\left(\mathrm{z}^{+}\right)}[\mathrm{tf} / \mathrm{m}]$ & -40.95 & - \\
$\mathrm{N}_{\mathrm{xy}\left(\mathrm{z}^{+}\right)}[\mathrm{tf} / \mathrm{m}]$ & -0.25 & - \\
$\mathrm{N}_{\mathrm{cl}\left(\mathrm{z}^{+}\right)}[\mathrm{tf} / \mathrm{m}]$ & 77.24 & $(25)$ \\
$\mathrm{N}_{\mathrm{c} 2\left(\mathrm{z}^{+}\right)}[\mathrm{tf} / \mathrm{m}]$ & -40.95 & $(26)$ \\
$\mathrm{NS}_{\mathrm{x}\left(\mathrm{z}^{+}\right)}[\mathrm{tf} / \mathrm{m}]$ & 77.24 & $(23)$ \\
$\mathrm{Nsy}_{(\mathrm{z}+}[\mathrm{tf} / \mathrm{m}]$ & 0.00 & - \\
$\mathrm{N}_{\mathrm{c}\left(\mathrm{z}^{+}\right)}[\mathrm{tf} / \mathrm{m}]$ & -40.95 & $(24)$ \\
$\operatorname{tg} \theta$ & -0.01 & $(22)$ \\
\hline
\end{tabular}

\begin{tabular}{ccc}
\hline \multicolumn{3}{c}{ Element 2 - y-direction } \\
\hline Correction & Equation \\
\hline $\mathrm{Nsy}_{\mathrm{y}(\mathrm{z}) \text { shell }[\mathrm{tf} / \mathrm{m}]}$ & 79.98 & $(7)$ \\
$\mathrm{Nsy}(\mathrm{z}-)$ shell $[\mathrm{tf} / \mathrm{m}]$ & 54.62 & $(8)$ \\
\hline
\end{tabular}

Table 9. Correction of the position of the reinforcement in the x-direction and y-direction for elements 3 and 4.

\begin{tabular}{|c|c|c|}
\hline \multicolumn{3}{|c|}{ Element 3 - x-direction } \\
\hline \multicolumn{3}{|c|}{ No correction } \\
\hline \multicolumn{3}{|c|}{ Element 4 - x-direction } \\
\hline Correction & & Equation \\
\hline $\mathrm{NS}_{\mathrm{x}}(\mathrm{z}+)$ shell $[\mathrm{tf} / \mathrm{m}]$ & 138.71 & (9) \\
\hline$\Delta \mathrm{N}_{\mathrm{X}(\mathrm{z}-)}[\mathrm{tf} / \mathrm{m}]$ & -5.78 & (10) \\
\hline $\mathrm{N}_{\mathrm{x}(\mathrm{z}-)}[\mathrm{tf} / \mathrm{m}]$ & -254.21 & - \\
\hline $\mathrm{N}_{\mathrm{y}(\mathrm{z}-)}[\mathrm{tf} / \mathrm{m}]$ & -492.89 & - \\
\hline $\mathrm{N}_{\mathrm{xy}(\mathrm{z}-)}[\mathrm{tf} / \mathrm{m}]$ & -111.31 & - \\
\hline $\mathrm{N}_{\mathrm{cl}(\mathrm{z}-)}[\mathrm{tf} / \mathrm{m}]$ & -210.36 & $(25)$ \\
\hline $\mathrm{N}_{\mathrm{c} 2(\mathrm{z}-)}[\mathrm{tf} / \mathrm{m}]$ & -536.74 & (26) \\
\hline $\mathrm{NS}_{\mathrm{x}(\mathrm{z}-)}[\mathrm{tf} / \mathrm{m}]$ & 0.00 & - \\
\hline $\mathrm{Nsy}_{(\mathrm{z}-)}[\mathrm{tf} / \mathrm{m}]$ & 0.00 & - \\
\hline $\mathrm{N}_{\mathrm{c}(\mathrm{z}-)}[\mathrm{tf} / \mathrm{m}]$ & -536.74 & (26) \\
\hline $\operatorname{tg} \theta$ & - & - \\
\hline
\end{tabular}

\begin{tabular}{|c|c|c|}
\hline \multicolumn{3}{|c|}{ Element 3 - y-direction } \\
\hline \multicolumn{2}{|c|}{ Correction } & Equation \\
\hline 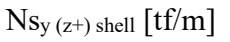 & 1.12 & (9) \\
\hline$\Delta \mathrm{N}_{\mathrm{y}(\mathrm{z}-)}[\mathrm{tf} / \mathrm{m}]$ & -0.05 & (10) \\
\hline $\mathrm{N}_{\mathrm{x}(\mathrm{z}-)}[\mathrm{tf} / \mathrm{m}]$ & -129.98 & - \\
\hline $\mathrm{N}_{\mathrm{y}(\mathrm{z}-)}[\mathrm{tf} / \mathrm{m}]$ & -525.75 & - \\
\hline $\mathrm{N}_{\mathrm{xy}(\mathrm{z}-)}[\mathrm{tf} / \mathrm{m}]$ & -63.20 & - \\
\hline $\mathrm{N}_{\mathrm{cl}(\mathrm{z}-)}[\mathrm{tf} / \mathrm{m}]$ & -120.13 & $(25)$ \\
\hline $\mathrm{N}_{\mathrm{c} 2(\mathrm{z}-)}[\mathrm{tf} / \mathrm{m}]$ & -535.60 & (26) \\
\hline $\mathrm{Ns}_{\mathrm{x}(\mathrm{z}-)}[\mathrm{tf} / \mathrm{m}]$ & 0.00 & - \\
\hline $\mathrm{Nsy}_{(\mathrm{z}-)}[\mathrm{tf} / \mathrm{m}]$ & 0.00 & - \\
\hline $\mathrm{N}_{\mathrm{c}(\mathrm{z}-)}[\mathrm{tf} / \mathrm{m}]$ & -535.60 & (26) \\
\hline $\operatorname{tg} \theta$ & - & - \\
\hline \multicolumn{3}{|c|}{ Element 4 - y-direction } \\
\hline \multicolumn{2}{|c|}{ Correction } & Equation \\
\hline Nsy $\left(z^{+}\right)$shell $[t f / m]$ & 1272.51 & (9) \\
\hline$\Delta \mathrm{N}_{\mathrm{y}(\mathrm{z}-)}[\mathrm{tf} / \mathrm{m}]$ & -53.02 & (10) \\
\hline $\mathrm{N}_{\mathrm{x}(\mathrm{z}-)}[\mathrm{tf} / \mathrm{m}]$ & -248.43 & - \\
\hline $\mathrm{N}_{\mathrm{y}(\mathrm{z}-)}[\mathrm{tf} / \mathrm{m}]$ & -492.89 & - \\
\hline $\mathrm{N}_{\mathrm{xy}(\mathrm{z}-)}[\mathrm{tf} / \mathrm{m}]$ & -111.31 & - \\
\hline $\mathrm{N}_{\mathrm{c} 1(\mathrm{z}-)}[\mathrm{tf} / \mathrm{m}]$ & -205.34 & $(25)$ \\
\hline $\mathrm{N}_{\mathrm{c} 2(\mathrm{z}-)}[\mathrm{tf} / \mathrm{m}]$ & -535.97 & (26) \\
\hline $\mathrm{Nsx}_{(\mathrm{z}-)}[\mathrm{tf} / \mathrm{m}]$ & 0.00 & - \\
\hline $\mathrm{Nsy}_{(\mathrm{z}-)}[\mathrm{tf} / \mathrm{m}]$ & 0.00 & - \\
\hline $\mathrm{N}_{\mathrm{c}(\mathrm{z}-)}[\mathrm{tf} / \mathrm{m}]$ & -535.97 & (26) \\
\hline $\operatorname{tg} \theta$ & - & - \\
\hline
\end{tabular}


The next step is to calculate the new thicknesses $\mathrm{a}_{\left(\mathrm{z}^{+}\right)}$and $\mathrm{a}_{(\mathrm{z}-)}$ for the upper and lower layers based on the forces $\mathrm{N}_{\mathrm{c}\left(\mathrm{z}^{+}\right)}$ and $\mathrm{N}_{\mathrm{c}(\mathrm{z}-)}$, respectively. For that, the value of $\mathrm{f}_{\mathrm{c}}$ must be found. For the lower layers of the elements 3 and 4 , which correspond to the case of designing IV and in which the concrete is under compression and uncracked, Equation 30 shall be used. For the other cases, the layers are cracked and $f_{c}$ must be evaluated by using Equation 33 . The thicknesses can then be determined from Equation 29. Table 10 presents the calculation of the thicknesses of the upper layers and Table 11 presents the calculation of the thicknesses of the lower layers.

Note that the new values of thickness $\mathrm{a}_{\left(\mathrm{z}^{+}\right.}$and $\mathrm{a}_{(\mathrm{z}-)}$ do not coincide with the initial values. Thus, the entire procedure should be repeated as many times as necessary so that the final values of thickness coincide with the initial values within a pre-established tolerance. Once the problem has converged, the reinforcement can be determined by Equations 27 and 28. For the shell elements in question, the final values of thickness and reinforcement are indicated in Table 12.

Table 10. Thicknesses of the upper layers.

\begin{tabular}{ccc}
\hline \multicolumn{3}{c}{ Element 1 } \\
\hline \multicolumn{3}{c}{ Case of designing III } \\
\hline$\varepsilon_{\mathrm{cp}}$ & -0.0020 & Equation \\
$\varepsilon_{\mathrm{yi}}$ & 0.00207 & - \\
$\varepsilon_{1}$ & 0.00207 & - \\
$\mathrm{f}_{\mathrm{c}}[\mathrm{MPa}]$ & 9.70 & $(39)$ \\
$\mathrm{a}(\mathrm{z}+)[\mathrm{m}]$ & 0.042 & $(33)$ \\
\hline \multicolumn{3}{c}{ Case of designing II } \\
\hline Thickness calculation \\
\hline$\varepsilon_{\mathrm{cp}}$ & -0.0020 & $(29)$ \\
$\varepsilon_{\mathrm{yi}}$ & 0.00207 & Equation \\
$\varepsilon_{1}$ & 0.00261 & - \\
$\mathrm{f}_{\mathrm{c}}[\mathrm{MPa}]$ & 8.98 & $(38)$ \\
$\mathrm{a}\left(\mathrm{z}^{+}\right)[\mathrm{m}]$ & 0.004 & $(33)$ \\
\hline
\end{tabular}

\begin{tabular}{|c|c|c|}
\hline \multicolumn{3}{|c|}{ Element 3} \\
\hline \multicolumn{3}{|c|}{ Case of designing II } \\
\hline \multicolumn{2}{|c|}{ Thickness calculation } & Equation \\
\hline$\varepsilon_{\mathrm{cp}}$ & -0.0020 & - \\
\hline$\varepsilon_{\mathrm{yi}}$ & 0.00207 & - \\
\hline$\varepsilon_{1}$ & 0.00386 & (38) \\
\hline $\mathrm{f}_{\mathrm{c}}[\mathrm{MPa}]$ & 7.89 & (33) \\
\hline $\mathrm{a}\left(\mathrm{z}^{+}\right)[\mathrm{m}]$ & 0.084 & $(29)$ \\
\hline \multicolumn{3}{|c|}{ Element 4} \\
\hline \multicolumn{3}{|c|}{ Case of designing I } \\
\hline \multicolumn{2}{|c|}{ Thickness calculation } & Equation \\
\hline$\varepsilon_{\mathrm{cp}}$ & -0.0020 & - \\
\hline Eyi & 0.00207 & - \\
\hline$\varepsilon_{1}$ & 0.00614 & (37) \\
\hline $\mathrm{f}_{\mathrm{c}}[\mathrm{MPa}]$ & 7.89 & (33) \\
\hline $\mathrm{a}_{(\mathrm{z}+)}[\mathrm{m}]$ & 0.117 & (29) \\
\hline
\end{tabular}

Table 11. Thicknesses of the lower layers.

\begin{tabular}{ccc}
\hline \multicolumn{3}{c}{ Element 1 } \\
\hline \multicolumn{3}{c}{ Case of designing I } \\
\hline \multicolumn{2}{c}{ Thickness calculation } & Equation \\
\hline$\varepsilon_{\mathrm{cp}}$ & -0.0020 & - \\
$\varepsilon_{\mathrm{yi}}$ & 0.00207 & - \\
$\varepsilon_{1}$ & 0.00614 & $(37)$ \\
$\mathrm{f}_{\mathrm{c}}[\mathrm{MPa}]$ & 7.89 & $(33)$ \\
$\mathrm{a}(\mathrm{z}-)[\mathrm{m}]$ & 0.070 & $(29)$ \\
\hline \multicolumn{3}{c}{ Case of designing I } \\
\hline \multicolumn{2}{c}{ Thickness calculation } & Equation \\
\hline$\varepsilon_{\mathrm{cp}}$ & -0.0020 & - \\
$\varepsilon_{\mathrm{yi}}$ & 0.00207 & - \\
$\varepsilon_{1}$ & 0.00614 & $(37)$ \\
$\mathrm{f}_{\mathrm{c}}[\mathrm{MPa}]$ & 7.89 & $(33)$ \\
$\mathrm{a}(\mathrm{z}-)[\mathrm{m}]$ & 0.024 & $(29)$ \\
\hline
\end{tabular}

\begin{tabular}{ccc}
\hline \multicolumn{3}{c}{ Element 3 } \\
\hline \multicolumn{3}{c}{ Case of designing IV } \\
\hline \multicolumn{2}{c}{ Thickness calculation } & Equation \\
\hline $\mathrm{f}_{\mathrm{c}}[\mathrm{MPa}]$ & 11.17 & $(30)$ \\
$\mathrm{a}(\mathrm{z}-\mathrm{m}]$ & 0.479 & $(29)$ \\
\hline
\end{tabular}

\begin{tabular}{ccc}
\hline \multicolumn{3}{c}{ Element 4} \\
\hline \multicolumn{3}{c}{ Case of designing IV } \\
\hline \multicolumn{2}{c}{ Thickness calculation } & Equation \\
\hline $\mathrm{f}_{\mathrm{c}}[\mathrm{MPa}]$ & 11.17 & $(30)$ \\
$\mathrm{a}(\mathrm{z}-\mathrm{m})[\mathrm{m}]$ & 0.480 & $(29)$ \\
\hline
\end{tabular}


Table 12. Final design of the shell elements.

\begin{tabular}{|c|c|}
\hline \multicolumn{2}{|c|}{ Element 1} \\
\hline \multicolumn{2}{|c|}{ Final results } \\
\hline $\mathrm{a}\left(\mathrm{z}^{+}\right)[\mathrm{m}]$ & 0.040160 \\
\hline $\mathrm{f}_{\mathrm{c}}[\mathrm{MPa}]$ & 9.68 \\
\hline$\theta$ [degrees] & 2.97 \\
\hline $\mathrm{a}_{(\mathrm{z}-)}[\mathrm{m}]$ & 0.064037 \\
\hline $\mathrm{f}_{\mathrm{c}}[\mathrm{MPa}]$ & 7.89 \\
\hline$\theta$ [degrees] & 45.00 \\
\hline $\mathrm{A}_{\mathrm{sx}(\mathrm{z}+)}\left[\mathrm{cm}^{2} / \mathrm{m}\right]$ & 13.85 \\
\hline $\mathrm{A}_{\mathrm{sx}(\mathrm{z}-)}\left[\mathrm{cm}^{2} / \mathrm{m}\right]$ & 38.55 \\
\hline $\mathrm{A}_{\mathrm{sy}\left(\mathrm{z}^{+}\right)}\left[\mathrm{cm}^{2} / \mathrm{m}\right]$ & 0.00 \\
\hline$A_{\text {sy }(z-)}\left[\mathrm{cm}^{2} / \mathrm{m}\right]$ & 12.59 \\
\hline \multicolumn{2}{|c|}{ Element 3} \\
\hline \multicolumn{2}{|c|}{ Final results } \\
\hline $\mathrm{a}_{\left(\mathrm{z}^{+}\right)}[\mathrm{m}]$ & 0.056171 \\
\hline $\mathrm{f}_{\mathrm{c}}[\mathrm{MPa}]$ & 7.89 \\
\hline$\theta$ [degrees] & -53.41 \\
\hline $\mathrm{a}(\mathrm{z}-)[\mathrm{m}]$ & 0.536420 \\
\hline $\mathrm{f}_{\mathrm{c}}[\mathrm{MPa}]$ & 11.17 \\
\hline$\theta$ [degrees] & 0.00 \\
\hline $\mathrm{A}_{\mathrm{sx}\left(\mathrm{z}^{+}\right)}\left[\mathrm{cm}^{2} / \mathrm{m}\right]$ & 0.00 \\
\hline $\mathrm{A}_{\mathrm{sx}(\mathrm{z}-)}\left[\mathrm{cm}^{2} / \mathrm{m}\right]$ & 0.00 \\
\hline $\mathrm{A}_{\mathrm{sy}\left(\mathrm{z}^{+}\right)}\left[\mathrm{cm}^{2} / \mathrm{m}\right]$ & 13.46 \\
\hline $\mathrm{A}_{\mathrm{sy}(\mathrm{z}-)}\left[\mathrm{cm}^{2} / \mathrm{m}\right]$ & 0.00 \\
\hline
\end{tabular}

\begin{tabular}{|c|c|}
\hline \multicolumn{2}{|c|}{ Element 2} \\
\hline \multicolumn{2}{|c|}{ Final results } \\
\hline $\mathrm{a}_{(\mathrm{z}+)}[\mathrm{m}]$ & 0.005969 \\
\hline $\mathrm{f}_{\mathrm{c}}[\mathrm{MPa}]$ & 8.40 \\
\hline$\theta$ [degrees] & -63.07 \\
\hline $\mathrm{a}_{(\mathrm{z}-)}[\mathrm{m}]$ & 0.021726 \\
\hline $\mathrm{f}_{\mathrm{c}}[\mathrm{MPa}]$ & 7.89 \\
\hline$\theta$ [degrees] & -45.00 \\
\hline $\mathrm{A}_{\mathrm{sx}(\mathrm{z}+)}\left[\mathrm{cm}^{2} / \mathrm{m}\right]$ & 0.00 \\
\hline $\mathrm{A}_{\mathrm{sx}(\mathrm{z}-)}\left[\mathrm{cm}^{2} / \mathrm{m}\right]$ & 1.80 \\
\hline $\mathrm{A}_{\text {sy }\left(\mathrm{z}^{+}\right)}\left[\mathrm{cm}^{2} / \mathrm{m}\right]$ & 18.32 \\
\hline $\mathrm{A}_{\text {sy }(\mathrm{z}-)}\left[\mathrm{cm}^{2} / \mathrm{m}\right]$ & 12.60 \\
\hline \multicolumn{2}{|c|}{ Element 4} \\
\hline \multicolumn{2}{|c|}{ Final results } \\
\hline $\mathrm{a}_{(\mathrm{z}+)}[\mathrm{m}]$ & 0.137339 \\
\hline $\mathrm{f}_{\mathrm{c}}[\mathrm{MPa}]$ & 7.89 \\
\hline$\theta$ [degrees] & 45.00 \\
\hline $\mathrm{a}_{(\mathrm{z}-)}[\mathrm{m}]$ & 0.537011 \\
\hline $\mathrm{f}_{\mathrm{c}}[\mathrm{MPa}]$ & 11.17 \\
\hline$\theta$ [degrees] & 0.00 \\
\hline $\mathrm{A}_{\mathrm{sx}\left(\mathrm{z}^{+}\right)}\left[\mathrm{cm}^{2} / \mathrm{m}\right]$ & 41.56 \\
\hline $\mathrm{A}_{\mathrm{sx}(\mathrm{z}-)}\left[\mathrm{cm}^{2} / \mathrm{m}\right]$ & 0.00 \\
\hline $\mathrm{A}_{\text {sy }\left(\mathrm{z}^{+}\right)}\left[\mathrm{cm}^{2} / \mathrm{m}\right]$ & 308.64 \\
\hline $\mathrm{A}_{\mathrm{sy}(\mathrm{z}-)}\left[\mathrm{cm}^{2} / \mathrm{m}\right]$ & 0.00 \\
\hline
\end{tabular}

\section{VERIFICATION BY THE MULTILAYER METHOD}

One possibility for the verification of shell elements is to use the idea proposed by Kollegger et al. [13] as a basis, which will be described in detail below. It is worth mentioning that the formulation was adapted to incorporate new constitutive models based on NBR 6118/2014 [1] and on experimental results obtained by Vecchio and Collins [17]. Verifications of the examples presented in Section 2.2 will be made based on the new formulation, which can be used for both thin and thick shells.

\subsection{Formulation}

The idea proposed by Kollegger et al. [13] consists in dividing the reinforced concrete shell element with thickness $h$ into concrete layers with thickness $h_{i}$ and distance $z_{i}$ from the center of the element. The author also identifies the reinforcement layers in $\mathrm{x}$-direction and $\mathrm{y}$-direction with areas $\mathrm{A}_{\mathrm{sxi}}$ and $\mathrm{A}_{\mathrm{syi}}$, which have distance $\mathrm{z}_{\mathrm{sxi}}$ and $\mathrm{z}_{\mathrm{syi}}$ from the center of the element, respectively. Figure 7 illustrates the proposed element.

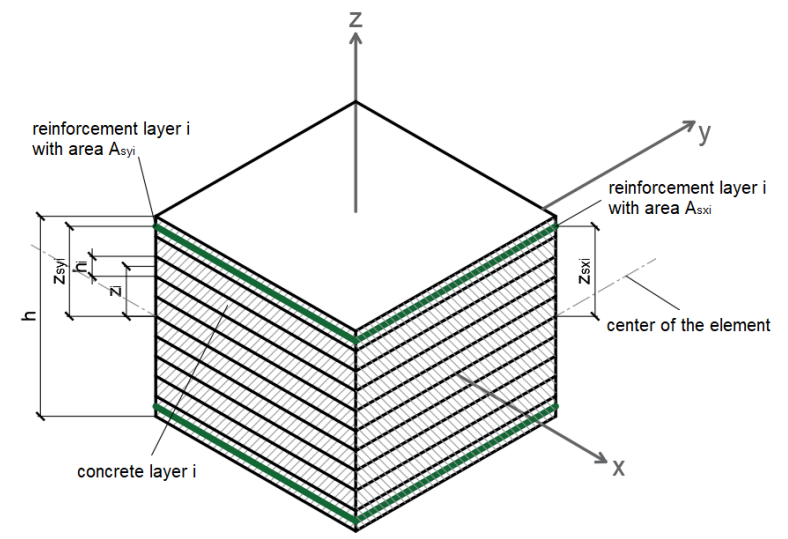

Figure 7. Reinforced concrete shell element idealized by Kollegger et al. [13]. 
It is assumed that the normal strains $\varepsilon_{\mathrm{x}}$ and $\varepsilon_{\mathrm{y}}$ and the tangential strain $\gamma_{\mathrm{xy}}$ vary linearly along the thickness of the shell element. Thus, from the strain values $\varepsilon_{0 x}, \varepsilon_{0 y}$ and $\gamma_{0 x y}$ in the center of the element and from the curvatures $1 / r_{x}, 1 / r_{y}$ and $1 / r_{x y}$ related to each strain, respectively, it is possible to determine the strains $\varepsilon_{x i}$, $\varepsilon_{y i}$ and $\gamma_{x y i}$ in the center of each concrete layer and the strains $\varepsilon_{\mathrm{sxi}}$ and $\varepsilon_{\text {syi }}$ in the center of each reinforcement layer, assuming similar strains for concrete and steel. For that, Equations 42 to 46 shall be used.

$\varepsilon_{x i}=\varepsilon_{0 x}+\frac{1}{r_{x}} \cdot z_{i}$

$\varepsilon_{y i}=\varepsilon_{0 y}+\frac{1}{r_{y}} \cdot z_{i}$

$\gamma_{x y i}=\gamma_{0 x y}+\frac{1}{r_{x y}} \cdot z_{i}$

$\varepsilon_{s x i}=\varepsilon_{0 x}+\frac{1}{r_{x}} \cdot z_{s x i}$

$\varepsilon_{s y i}=\varepsilon_{0 y}+\frac{1}{r_{y}} \cdot z_{s y i}$

For the concrete, it is necessary to determine the principal strains $\varepsilon_{1 \mathrm{i}}$ and $\varepsilon_{2 \mathrm{i}}$ in each layer by Equations 47 and (48). The direction $\theta_{\mathrm{i}}$ of these principal strains is coincident with the direction of the principal stresses and can be determine by Equation 49 .

$\varepsilon_{l i}=\frac{\varepsilon_{x i}+\varepsilon_{y i}}{2}+\sqrt{\left(\frac{\varepsilon_{x i}-\varepsilon_{y i}}{2}\right)^{2}+\left(\frac{\gamma_{x y i}}{2}\right)^{2}}$

$\varepsilon_{2 i}=\frac{\varepsilon_{x i}+\varepsilon_{y i}}{2}-\sqrt{\left(\frac{\varepsilon_{x i}-\varepsilon_{y i}}{2}\right)^{2}+\left(\frac{\gamma_{x y i}}{2}\right)^{2}}$

$$
-\operatorname{tg} \theta_{i}=\frac{\gamma_{x y i} / 2}{\varepsilon_{y i}-\varepsilon_{1 i}}
$$

From the principal strains and by using a suitable constitutive model for the concrete, it is possible to determine the principal stresses in each concrete layer. The model chosen for the present work is the parabola-rectangle diagram of NBR 6118/2014 [1], which is adapted so that the peak stress depends on the biaxial state of concrete stresses, that is, depends on $\varepsilon_{1 \mathrm{i}}$, as proposed by Vecchio and Collins [17]. Figure 8a illustrates the proposed model, in which $\varepsilon_{\mathrm{c} 2}$ is the shortening strain of concrete at the beginning of the plastic branch and $\varepsilon_{\mathrm{cu}}$ is the shortening strain of concrete at failure. The parameter $\beta$ is based on the experimental results obtained by Vecchio and Collins [17] and is given by Equation 50, taking into account whether or not the concrete is cracked. The tensile strength of the concrete is neglected. 


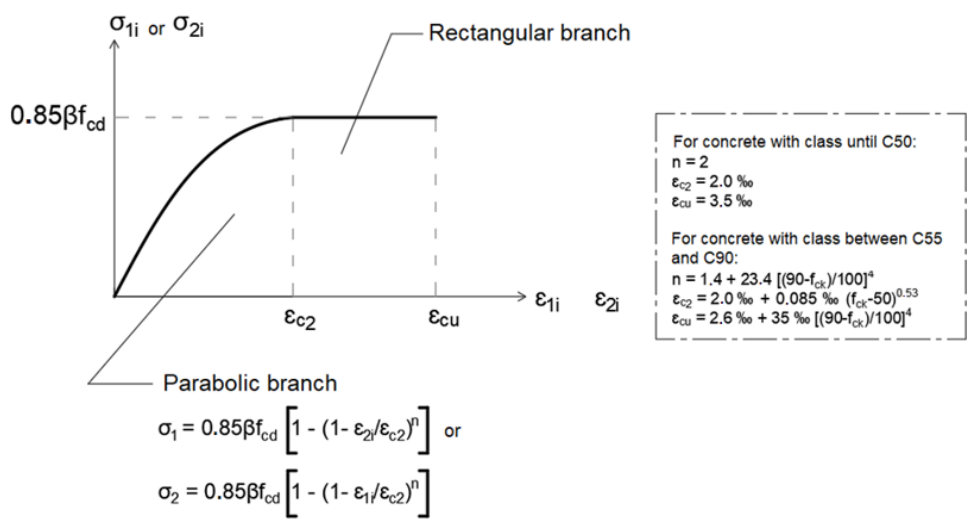

(a)

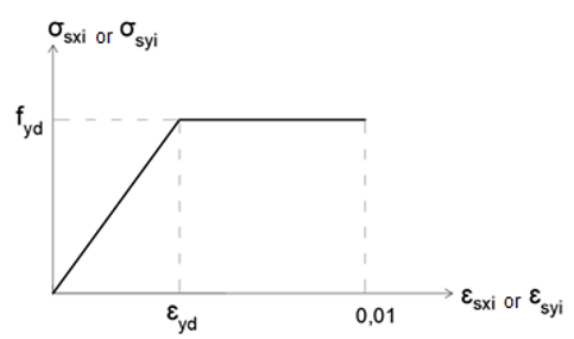

(b)

Figure 8. Constitutive models. (a) Concrete. (b) Steel.

$\beta=\frac{1}{0.8-0.34\left(\varepsilon_{1 i} / \varepsilon_{c 2}\right)}$, where $\frac{0.6}{0.85} \leq \beta \leq 1$

Once the stresses in each concrete layer are found, it is possible to determine, through the integration of such stresses on the thickness of the element, the concrete resistance loads that partially equilibrate the applied loads; however, as the applied loads are referenced in relation to the $\mathrm{x}$-direction and $\mathrm{y}$-direction, it is first necessary to determine the stresses according to such directions. Equations 51 to 53 calculate $\sigma_{\mathrm{xi}}, \sigma_{\mathrm{yi}}$ and $\tau_{\mathrm{xyi}}$ for each concrete layer.

$\sigma_{x i}=\sigma_{2 i} \sin ^{2} \theta_{i}+\sigma_{1 i} \cos ^{2} \theta_{i}$

$\sigma_{y i}=\sigma_{2 i} \cos ^{2} \theta_{i}+\sigma_{1 i} \sin ^{2} \theta_{i}$

$\tau_{x y i}=\left(\sigma_{1 i}-\sigma_{2 i}\right) \sin \theta_{i} \cos \theta_{i}$

Since the problem is discretized into layers, the integration of stresses on the thickness of the element can be easily developed for determining the concrete resistance loads $N_{c x}, N_{c y}, N_{c x y}, M_{c x}, M_{c y}$ and $M_{c x y}$ that partially equilibrate the applied loads $\mathrm{N}_{\mathrm{x}}, \mathrm{N}_{\mathrm{y}}, \mathrm{N}_{\mathrm{xy}}, \mathrm{M}_{\mathrm{x}}, \mathrm{M}_{\mathrm{y}}$ and $\mathrm{M}_{\mathrm{xy}}$. For that, Equations 54 to 59 can be used.

$N_{c x}=\Sigma\left(\sigma_{x i} \cdot h_{i}\right)$

$N_{c y}=\Sigma\left(\sigma_{y i} \cdot h_{i}\right)$

$N_{c x y}=\Sigma\left(\tau_{x y i} \cdot h_{i}\right)$

$M_{c x}=\Sigma\left(\sigma_{x i} \cdot h_{i} \cdot z_{i}\right)$ 
$M_{c y}=\Sigma\left(\sigma_{y i} \cdot h_{i} \cdot z_{i}\right)$

$M_{c x y}=\Sigma\left(\tau_{x y i} \cdot h_{i} \cdot z_{i}\right)$

The same procedure performed for the concrete, that is, the determination of the stresses from the strains and the subsequent determination of the resistance loads from the integration of the stresses, can be performed for the steel by employing a suitable constitutive model. The model assumed in the present work is that given by NBR6118/2014 [1], which is described in Figure 8b.

Since the reinforcement is not responsible for resisting shear stresses, the analysis of stresses can be performed directly according to the $\mathrm{x}$-direction and $\mathrm{y}$-direction. Once the stress in each reinforcement layer is determined, it is possible to proceed with the integration of such stress on the reinforcement cross section in order to obtain the steel resistance loads $N_{s x}, N_{s y}, M_{s x}$ and $M_{s y}$ that partially equilibrate the applied loads $N_{x}, N_{y}, M_{x}$ and $M_{y}$, respectively. The loads resisted by the reinforcement are given by Equations 60 to 63 .

$$
N_{s x}=\Sigma\left(\sigma_{s x i} \cdot A_{s x i}\right)
$$

$N_{s y}=\Sigma\left(\sigma_{s y i} \cdot A_{s y i}\right)$

$M_{s x}=\Sigma\left(\sigma_{s x i} \cdot A_{s x i} \cdot z_{s x i}\right)$

$M_{s y}=\Sigma\left(\sigma_{s y i} \cdot A_{s y i} \cdot z_{s y i}\right)$

To obtain the final resistance loads $N_{R x}, N_{R y}, N_{R x y}, M_{R x}, M_{R y}$ and $M_{R x y}$, it is necessary to sum the loads resisted by the concrete and the reinforcement. Such resistance loads must equilibrate the applied loads so that the shell element can be given as verified.

It is clear that the procedure for determining whether or not a reinforced concrete shell element resist the applied loads is quite simple when the strains in the center of the element and the corresponding curvatures are known. But how is it possible to know if there is any set of strains in the center of the shell element and of curvatures that generates internal loads that resist the applied loads? To solve this problem, the Newton-Raphson nonlinear iterative method can be used. The applied loads $(\mathbf{S})$ must be equal to the resistance loads $(\mathbf{R})$ for equilibrium. It is also known that the resistance loads are function of the strains and curvatures $\varepsilon_{0 \mathrm{x}}, \varepsilon_{0 \mathrm{y}}, \gamma_{0 \mathrm{xy}}, 1 / \mathrm{r}_{\mathrm{x}}, 1 / \mathrm{r}_{\mathrm{y}}$ and $1 / \mathrm{r}_{\mathrm{xy}}$. Thus, one can write Equation 64.

$\mathbf{f}(\boldsymbol{\varepsilon})=0$ where $\mathbf{f}=\mathbf{R}-\mathbf{S}$ and $\boldsymbol{\varepsilon}$ is the vector of strains and curvatures

By using the Newton-Raphson method, from an estimate $\mathrm{i}$ of strains and curvatures, the values of strains and curvatures of the next iteration $\mathrm{i}+1$ are obtained by Equation $65 . \partial \mathbf{f} / \partial \boldsymbol{\varepsilon}\left(\boldsymbol{\varepsilon}_{i}\right)$ stands for the tangent matrix of the problem, which can be determined analytically or numerically. The use of the Newton-Raphson method implies choosing an initial estimate for $\varepsilon_{0 \mathrm{x}}, \varepsilon_{0 \mathrm{y}}, \gamma_{0 \mathrm{xy}}, 1 / \mathrm{r}_{\mathrm{x}}, 1 / \mathrm{r}_{\mathrm{y}}$ and $1 / \mathrm{r}_{\mathrm{xy}}$. The idea of Kollegger et al. [13] is to use the elastic estimate of strains and curvatures.

$\left[\frac{\partial \mathbf{f}}{\partial \boldsymbol{\varepsilon}}\left(\boldsymbol{\varepsilon}_{i}\right)\right]\left(\boldsymbol{\varepsilon}_{i+1}-\boldsymbol{\varepsilon}_{i}\right)=-\mathbf{f}\left(\boldsymbol{\varepsilon}_{i}\right)$

The iterative method was computationally implemented and employed to verify the reinforced concrete shell elements of Section 2.2. 


\subsection{Numerical examples}

From the results obtained in the design performed in Section 2.2, the shell elements were verified by using the multilayer method described in Section 3.1. By using the Newton-Raphson iterative method, it is concluded that the equilibrium between the resistance loads and the applied loads can be reached with strains within the limits defined by NBR 6118/2014 [1]. Table 13, Table 14 and Table 15 present the strains, stresses and resistance loads calculated for the final equilibrium condition of the shell element 1 . The strains in the center of the element and the curvatures found for the equilibrium condition are summarized in Table 16 not only for element 1 but also for elements 2, 3 and 4 . The equilibrium is also possible for the elements 2, 3 and 4 with reinforcement approximately equal to that calculated by the three-layer method. For elements 3 and 4 , it would even be possible to reduce the reinforcement because the concrete and steel strains are below the limits established by NBR 6118/2014 [1]. It is worth mentioning that the elements 3 and 4 are not over dimensioned in the sense that the increase in the loads would yield the reinforcement before crushing the concrete. Note that differences begin to occur when, in the three-layer method, the thicknesses of the upper and lower concrete layers necessary for the equilibrium increase in relation to the shell thickness, as occurs in elements 3 and 4 . As the thicknesses of the layers necessary for the equilibrium were limited to $0.45 \mathrm{~d}$ in the present paper ( $\mathrm{d}$ is the effective depth of the section), the differences are still minimal, but the increase in the loads can lead to larger thicknesses and greater differences between the two models. This is because the assumptions of uniformization of the concrete stresses and of strains equal to $\varepsilon_{\mathrm{cp}}$ begin to distance from the assumptions of the parabola-rectangle diagram and of the linear variation of concrete strains along the thickness of the element, respectively.

Table 13. Multilayer method: input data of shell element 1.

\begin{tabular}{|c|c|c|c|c|c|}
\hline $\begin{array}{c}\mathbf{f}_{\text {ck }} \\
(\mathrm{MPa})\end{array}$ & $\begin{array}{c}\text { h } \\
(\mathrm{m})\end{array}$ & & & & \\
\hline 20 & 1.5 & & & & \\
\hline $\begin{array}{c}\varepsilon_{0 x} \\
(\% 0)\end{array}$ & $\begin{array}{c}\varepsilon_{0 y} \\
(\%)\end{array}$ & $\begin{array}{l}\gamma_{0 x y} \\
(\%)\end{array}$ & $\begin{array}{c}1 / \mathbf{r}_{\mathbf{x}} \\
(\% \mathrm{~m} / \mathrm{m})\end{array}$ & $\begin{array}{c}1 / \mathbf{r}_{\mathbf{y}} \\
(\% o / \mathbf{m})\end{array}$ & $\begin{array}{c}1 / \mathbf{r}_{\mathbf{x y}} \\
(\% \mathrm{mo} / \mathrm{m})\end{array}$ \\
\hline 3.1494 & 1.0386 & 2.4179 & 2.2759 & -1.9826 & -3.3593 \\
\hline
\end{tabular}

\begin{tabular}{|c|c|c|c|c|c|}
\hline $\begin{array}{c}\mathbf{N}_{\mathbf{x}} \\
(\mathbf{t f} / \mathbf{m})\end{array}$ & $\begin{array}{c}\mathbf{N}_{\mathbf{y}} \\
(\mathbf{t f} / \mathbf{m})\end{array}$ & $\begin{array}{c}\mathbf{N}_{\mathbf{x y}} \\
(\mathbf{t f} / \mathbf{m})\end{array}$ & $\begin{array}{c}\mathbf{M}_{\mathbf{x}} \\
(\mathbf{t f} \cdot \mathbf{m} / \mathbf{m})\end{array}$ & $\begin{array}{c}\mathbf{M}_{\mathbf{y}} \\
(\mathbf{t f} \cdot \mathbf{m} / \mathbf{m})\end{array}$ & $\begin{array}{c}\mathbf{M}_{\mathbf{x y}} \\
(\mathbf{t f} \cdot \mathbf{m} / \mathbf{m})\end{array}$ \\
\hline 202.46 & -9.31 & 27.26 & -28.79 & -36.28 & -16.66 \\
\hline
\end{tabular}

\begin{tabular}{|c|c|c|c|c|c|c|}
\hline $\mathbf{i}$ & $\begin{array}{c}\mathbf{h}_{\mathbf{i}} \\
(\mathbf{m})\end{array}$ & $\begin{array}{c}\mathbf{Z}_{\mathbf{i}} \\
(\mathbf{m})\end{array}$ & $\begin{array}{c}\text { Asxi } \\
\left(\mathbf{c m}^{2}\right)\end{array}$ & $\begin{array}{l}\text { Zsxi } \\
\text { (m) }\end{array}$ & $\begin{array}{c}A_{s y i} \\
\left(\mathbf{c m}^{2}\right)\end{array}$ & $\begin{array}{l}Z_{\text {syi }} \\
(\mathbf{m})\end{array}$ \\
\hline 1 & 0.15 & 0.675 & 14.00 & 0.55 & 0.00 & 0.55 \\
\hline 2 & 0.15 & 0.525 & 39.70 & -0.477 & 12.70 & -0.477 \\
\hline 3 & 0.15 & 0.375 & & & & \\
\hline 4 & 0.15 & 0.225 & & & & \\
\hline 5 & 0.15 & 0.075 & & & & \\
\hline 6 & 0.15 & -0.075 & & & & \\
\hline 7 & 0.15 & -0.225 & & & & \\
\hline 8 & 0.15 & -0.375 & & & & \\
\hline 9 & 0.15 & -0.525 & & & & \\
\hline 10 & 0.15 & -0.675 & & & & \\
\hline
\end{tabular}

\begin{tabular}{|c|c|c|c|c|c|}
\hline $\begin{array}{c}\mathbf{N}_{R x} \\
(\mathbf{t f} / \mathbf{m})\end{array}$ & $\begin{array}{c}\mathbf{N}_{\mathbf{R y}} \\
(\mathbf{t f} / \mathbf{m})\end{array}$ & $\begin{array}{c}\mathbf{N}_{\mathbf{R y}} \\
(\mathbf{t f} / \mathbf{m})\end{array}$ & $\begin{array}{c}\mathbf{M}_{\mathbf{R x}} \\
(\mathbf{t f} \cdot \mathbf{m} / \mathbf{m})\end{array}$ & $\begin{array}{c}\mathbf{M}_{\mathbf{R y}} \\
(\mathbf{t f} \cdot \mathbf{m} / \mathbf{m})\end{array}$ & $\begin{array}{c}\mathbf{M}_{\mathbf{R x y}} \\
(\mathbf{t f} \cdot \mathbf{m} / \mathbf{m})\end{array}$ \\
\hline 202.46 & -9.31 & 27.26 & -28.79 & -36.28 & -16.66 \\
\hline
\end{tabular}

Table 14. Multilayer method: equilibrium of shell element 1 (part 1).

\begin{tabular}{|c|c|c|c|c|c|c|c|c|c|c|c|}
\hline $\mathbf{i}$ & $\begin{array}{c}\mathcal{E}_{\mathrm{xi}} \\
(\%)\end{array}$ & $\begin{array}{c}\varepsilon_{y i} \\
(\%)\end{array}$ & $\begin{array}{c}\gamma_{x y i} / 2 \\
(\%)\end{array}$ & $\begin{array}{c}\varepsilon_{1 \mathrm{i}} \\
(\%)\end{array}$ & $\begin{array}{c}\varepsilon_{2 i} \\
(\% o)\end{array}$ & $\begin{array}{r}\theta_{\mathbf{i}} \\
\left({ }^{\circ}\right) \\
\end{array}$ & $\begin{array}{l}\varepsilon_{\text {sxi }} \\
(\%)\end{array}$ & $\begin{array}{l}\varepsilon_{\text {syi }} \\
(\%)\end{array}$ & $\begin{array}{r}\sigma_{c, \text { peak }} \\
\left(t \mathbf{t f} / \mathbf{m}^{2}\right)\end{array}$ & $\begin{array}{c}\sigma_{1 i} \\
\left(t \mathbf{t} / \mathbf{m}^{2}\right) \\
\end{array}$ & $\begin{array}{c}\sigma_{2 i} \\
\left(t f / m^{2}\right)\end{array}$ \\
\hline 1 & 4.6856 & -0.2997 & 0.0752 & 4.6868 & -0.3008 & 0.8639 & 4.4011 & -0.0519 & 857.14 & 0.00 & -238.45 \\
\hline 2 & 4.3442 & -0.0023 & 0.3271 & 4.3687 & -0.0268 & 4.2803 & 2.0638 & 1.9842 & 857.14 & 0.00 & -22.80 \\
\hline 3 & 4.0029 & 0.2951 & 0.5791 & 4.0912 & 0.2068 & 8.6736 & & & 857.14 & 0.00 & 0.00 \\
\hline 4 & 3.6615 & 0.5925 & 0.8310 & 3.8721 & 0.3819 & 14.2195 & & & 857.14 & 0.00 & 0.00 \\
\hline 5 & 3.3201 & 0.8899 & 1.0830 & 3.7327 & 0.4773 & 20.8549 & & & 857.14 & 0.00 & 0.00 \\
\hline 6 & 2.9787 & 1.1872 & 1.3349 & 3.6906 & 0.4754 & 28.0695 & & & 857.14 & 0.00 & 0.00 \\
\hline 7 & 2.6373 & 1.4846 & 1.5869 & 3.7493 & 0.3727 & 35.0198 & & & 857.14 & 0.00 & 0.00 \\
\hline 8 & 2.2959 & 1.7820 & 1.8389 & 3.8957 & 0.1823 & 41.0225 & & & 857.14 & 0.00 & 0.00 \\
\hline 9 & 1.9546 & 2.0794 & 2.0908 & 4.1087 & -0.0748 & 45.8551 & & & 857.14 & 0.00 & -62.88 \\
\hline 10 & 1.6132 & 2.3768 & 2.3428 & 4.3686 & -0.3787 & 49.6282 & & & 857.14 & 0.00 & -293.86 \\
\hline
\end{tabular}


Table 15. Multilayer method: equilibrium of shell element 1 (part 2).

\begin{tabular}{|c|c|c|c|c|c|c|c|c|c|c|}
\hline i & $\mathbf{N}_{\text {sxi }}(\mathbf{t f} / \mathbf{m})$ & $\mathbf{N}_{\text {syi }}(\mathbf{t f} / \mathrm{m})$ & $N_{\text {cxi }}(t \mathbf{t f} / \mathbf{m})$ & $\mathbf{N}_{\text {cyi }}(\mathbf{t f} / \mathbf{m})$ & $\begin{array}{c}N_{c x y i} \\
(t f / m)\end{array}$ & $\begin{array}{c}M_{s x i} \\
\text { (tf.m/m) }\end{array}$ & $\begin{array}{c}M_{\text {syi }} \\
\text { (tf.m/m) }\end{array}$ & $\begin{array}{c}M_{\mathrm{cxi}} \\
\text { (tf.m/m) }\end{array}$ & $\begin{array}{c}M_{c y i} \\
\text { (tf.m/m) }\end{array}$ & $\begin{array}{c}M_{c x y i} \\
\text { (tf.m/m) }\end{array}$ \\
\hline 1 & 60.87 & 0.00 & -0.01 & -35.76 & 0.54 & 33.48 & 0.00 & -0.01 & -24.14 & 0.36 \\
\hline 2 & 172.06 & 52.92 & -0.02 & -3.40 & 0.25 & -82.07 & -25.24 & -0.01 & -1.79 & 0.13 \\
\hline 3 & 0.00 & 0.00 & 0.00 & 0.00 & 0.00 & 0.00 & 0.00 & 0.00 & 0.00 & 0.00 \\
\hline 4 & 0.00 & 0.00 & 0.00 & 0.00 & 0.00 & 0.00 & 0.00 & 0.00 & 0.00 & 0.00 \\
\hline 5 & 0.00 & 0.00 & 0.00 & 0.00 & 0.00 & 0.00 & 0.00 & 0.00 & 0.00 & 0.00 \\
\hline 6 & 0.00 & 0.00 & 0.00 & 0.00 & 0.00 & 0.00 & 0.00 & 0.00 & 0.00 & 0.00 \\
\hline 7 & 0.00 & 0.00 & 0.00 & 0.00 & 0.00 & 0.00 & 0.00 & 0.00 & 0.00 & 0.00 \\
\hline 8 & 0.00 & 0.00 & 0.00 & 0.00 & 0.00 & 0.00 & 0.00 & 0.00 & 0.00 & 0.00 \\
\hline 9 & 0.00 & 0.00 & -4.86 & -4.58 & 4.71 & 0.00 & 0.00 & 2.55 & 2.40 & -2.47 \\
\hline 10 & 0.00 & 0.00 & -25.58 & -18.49 & 21.75 & 0.00 & 0.00 & 17.27 & 12.48 & -14.68 \\
\hline
\end{tabular}

\begin{tabular}{|l|l|l|l|l|l|l|l|l|l|l|}
\hline$\Sigma$ & 232.93 & 52.92 & -30.47 & -62.23 & 27.26 & -48.59 & -25.24 & 19.80 & -11.04 & -16.66 \\
\hline
\end{tabular}

Table 16. Strains and curvatures of the shell elements 1,2,3 and 4 for the equilibrium condition.

\begin{tabular}{cc}
\hline \multicolumn{1}{c}{ Element 1 } \\
\hline$\varepsilon_{0 \mathrm{x}}[\% \mathrm{o}]$ & 3.149 \\
$\varepsilon_{0 \mathrm{y}}[\% \mathrm{o}]$ & 1.039 \\
$\gamma_{0 \mathrm{xy}}[\% \mathrm{o}]$ & 2.418 \\
$1 / \mathrm{r}_{\mathrm{x}}[\% \mathrm{~m} / \mathrm{m}]$ & 2.276 \\
$1 / \mathrm{r}_{\mathrm{y}}[\% \mathrm{~m} / \mathrm{m}]$ & -1.983 \\
$1 / \mathrm{r}_{\mathrm{xy}}[\% \mathrm{~m}]$ & -3.359 \\
\hline \multicolumn{1}{c}{ Element 3 } & \\
\hline$\varepsilon_{0 \mathrm{x}}[\% \mathrm{o}]$ & -0.062 \\
$\varepsilon_{0 \mathrm{y}}[\% \mathrm{o}]$ & 0.100 \\
$\gamma_{0 \mathrm{xy}}[\% \mathrm{o}]$ & -0.397 \\
$1 / \mathrm{r}_{\mathrm{x}}[\% \mathrm{~m}]$ & 0.233 \\
$1 / \mathrm{r}_{\mathrm{y}}[\% \mathrm{~m} / \mathrm{m}]$ & 2.819 \\
$1 / \mathrm{r}_{\mathrm{xy}}[\% \mathrm{~m}]$ & -0.411 \\
\hline
\end{tabular}

\begin{tabular}{cc}
\hline \multicolumn{1}{c}{ Element 2 } \\
\hline$\varepsilon_{0 x}[\% \mathrm{o}]$ & 1.275 \\
$\varepsilon_{0 \mathrm{y}}[\% \mathrm{o}]$ & 2.062 \\
$\gamma_{0 \mathrm{xy}}[\% \mathrm{o}]$ & -3.101 \\
$1 / \mathrm{r}_{\mathrm{x}}[\% \mathrm{~m}]$ & -1.380 \\
$1 / \mathrm{r}_{\mathrm{y}}[\% \mathrm{~m} / \mathrm{m}]$ & 0.008 \\
$1 / \mathrm{r}_{\mathrm{xy}}[\% \mathrm{~m} / \mathrm{m}]$ & 1.996 \\
\hline \multicolumn{1}{c}{ Element 4} & \\
\hline$\varepsilon_{0 \mathrm{x}}[\% \mathrm{o}]$ & 0.491 \\
$\varepsilon_{0 \mathrm{y}}[\% \mathrm{o}]$ & 0.229 \\
$\gamma_{0 \mathrm{xy}}[\% \mathrm{o}]$ & 1.233 \\
$1 / \mathrm{r}_{\mathrm{x}}[\% \mathrm{~m}]$ & 2.284 \\
$1 / \mathrm{r}_{\mathrm{y}}[\% \mathrm{~m} / \mathrm{m}]$ & 3.329 \\
$1 / \mathrm{r}_{\mathrm{xy}}[\% \mathrm{~m}]$ & 5.032 \\
\hline
\end{tabular}

\section{RESULTS AND DISCUSSIONS}

Having presented the design of four shell elements by the three-layer method and their verification by the multilayer method, it is valid to discuss some assumptions of both models.

It can be concluded from the results of Sections 2.2 and 3.2 that both formulations lead to the equilibrium between the resistance loads and the applied loads with the same amount of reinforcement, especially when the thicknesses of the concrete layers are not significant in relation to the thickness of the element. The increase in the loads can lead to an increase in the thicknesses of the layers, making the assumption of uniformization of concrete stresses and strains invalid. Therefore, it cannot be said that there is a total similarity between the strains and stresses in both models. In the three-layer method, it is assumed that the contribution of the concrete for the strength is given by means of constant stresses at the thicknesses of the upper and lower layers in the direction of the principal compression. It is used the maximum strength of the concrete reduced by the factor $\left(1-\frac{f_{c k}}{250}\right)$. The value of the maximum strength of the concrete, in its turn, depends on the state of cracking of the concrete, as it also occurs in the method of verification described. The concrete strain in the direction of the principal compression is assumed to be constant and equal to the strain that occurs at the peak strength of the concrete, and the strain in the reinforcement is always assumed to be equal to the yield strain of the steel. Besides this, the upper and lower layers, although contributing together for the equilibrium of the element, are treated separately in the evaluation of the stresses and strains, not having compatibility along the thickness.

In the multilayer method, unlike the three-layer method, it is possible to describe a more realistic constitutive behavior of the materials, in which the stress depends on the strain in each layer of concrete and reinforcement. The strains, in their turn, are not considered with the maximum values possible, but calculated along the thickness through 
the values obtained in the center of the element. See comparisons between the two models in Figure 9 and Figure 10, which are based on the shell element 1 of Section 2.2. There are differences in both stresses and strains. It is worth mentioning that the direction of the principal stresses is not coincident in both methods.
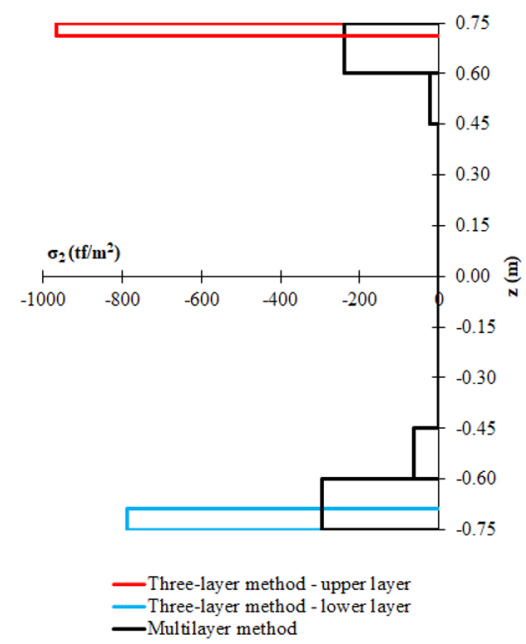

(a)

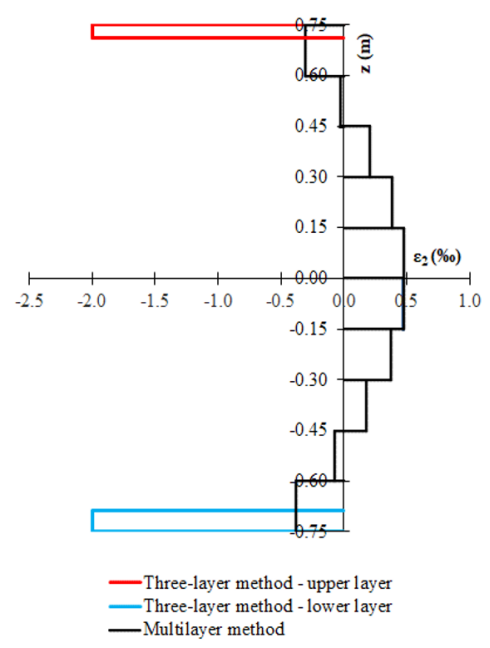

(b)

Figure 9. Three-layer method versus multilayer method. (a) Comparison of concrete stresses in the principal direction of compression for the shell element 1. (b) Comparison of concrete strains in the principal direction of compression for the shell element 1 .

Another limitation of the three-layer method is when compression reinforcement is required. In this case, the iterative process increases the thickness of each layer in order to increase the contribution of the concrete for the equilibrium, but, since the concrete alone is not able to equilibrate the applied compressive loads, the thicknesses of the layers exceed the half of the thickness of the element, with no solution. This is because the method is not able to predict compression reinforcement. The multilayer method, on the other hand, is able to verify elements with compression reinforcement.

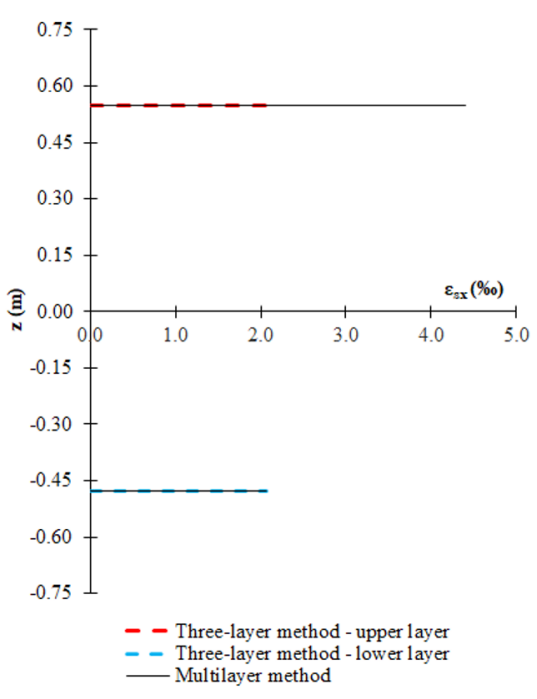

(a)

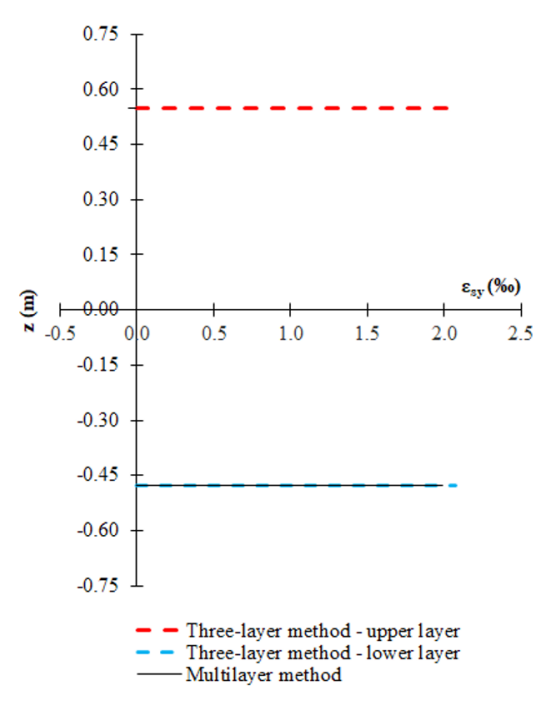

(b)

Figure 10. Three-layer method versus multilayer method. (a) Comparison of steel strains in the $x$-direction for the shell element 1. (b) Comparison of steel strains in the y-direction for the shell element 1. 
In short, the three-layer method is used to design shell elements, but with limitations regarding the strain compatibility and the determination of compression reinforcement. The multilayer method overcomes such limitations, but at first it is a verification method. So, would it not be possible to adopt the idea of the multilayer method for designing reinforced concrete shell elements? Kollegger et al. [13] points out a procedure for this. The idea is to start from a shell element with minimum reinforcement and to apply the external loads in steps. Thus, with the minimum reinforcement, the loads are increased until there is no more equilibrium. The reinforcement with the largest strain is then incremented as well as the loads. The procedure is repeated as many times as necessary to equilibrate the applied loads with allowable strains and stresses. An alternative to this method would be to start from the maximum reinforcement of the element and to decrease the reinforcement iteratively until the equilibrium is no longer possible or until the strains exceed the values established by the standards. Such procedure consists in the next step of the present research.

\section{CONCLUSIONS}

In practice, it is common to perform elastic-linear structural analyses aiming at obtaining the loads to which the reinforced concrete structures are subjected. The nonlinearity of the problem is taken into account in the models for reinforcement design and for verification of concrete in ultimate and service limit states. This is a simple practice with lower computational cost when compared to the nonlinear analysis, and it does not require prior knowledge of the amount and position of the reinforcement in the structural element. However, it is necessary to have design models that reproduce the behavior of concrete and steel together, calculating the reinforcement and verifying the concrete. In the case of the reinforced concrete shell element, the models are not so straightforward and are rarely described in detail in technical standards.

The present work addressed two formulations for reinforced concrete shell elements. The first formulation consists in the three-layer method, which is intended for designing and is based on the work of Colombo et al. [12], Model Code/1990 [10] and Lourenço and Figueiras [9]. The second one consists in the multilayer method that is based on and adapted from Kollegger et al. [13], which is intended for verification of shell elements. Both methods are compatible from the point of view of reinforcement when the concrete thicknesses required for the equilibrium are not significant. In other words, the design by the three-layer method imposing a limit for the thicknesses of the layers equal to $0.45 \mathrm{~d}$ was, for the examples presented, satisfactory in the verification by the multilayer method. However, the three-layer method does not consider the evaluation of strains and stresses along the thickness of the element. It becomes a rough approximation when the layer thickness tends to increase in relation to the shell thickness. The three-layer method is also restricted to the determination of tension reinforcement. The multilayer method, in its turn, despite not having the previous limitations, is a verification method and requires the prior knowledge of the reinforcement. Such problem could be overcome through iterative procedures as indicated by Kollegger et al. [13]. Thus, as future developments, it is predicted the implementation of an iterative method that, from initial values of reinforcement, minimum or maximum, finds the tension and compression reinforcement of reinforced concrete shell elements, obeying the constitutive models of the materials and the strain limitations prescribed by standards.

\section{ACKNOWLEDGEMENTS}

The authors thank the Department of Structural and Geotechnical Engineering of University of Sao Paulo.

\section{REFERENCES}

[1] Associação Brasileira de Normas Técnicas, Projeto de Estruturas de Concreto - Procedimento, NBR 6118, 2014.

[2] S. D. Kumar. "Two vector variable problems (plate and shell theory): finite element analysis." https://pt.slideshare.net/dharanimech/finite-element-analysis-plate-shell-skew-plate (accessed Sep. 25, 2020).

[3] E. Oñate, Structural Analysis with the Finite Element Method - Linear Statics: Beams, Plates and Shells, 1st ed. Barcelona: Springer, 2013.

[4] O. B. Isgor, “Analysis and design of reinforced concrete shell elements," M.S. thesis, Dept. Civ. Environ. Eng., Univ. Ottawa, Ottawa, 1997.

[5] J. Blaauwendraad, "Reinforcement design using linear analysis," in Plates and FEM. Dordrecht: Springer, 2009, pp. $291-318$.

[6] T. D. Hrynyk and F. J. Vecchio, "Capturing out-of-plane shear failures in the analysis of reinforced concrete shells," J. Struct. Eng., vol. 141, no. 12, pp. 1-11, 2015, http://dx.doi.org/10.1061/(asce)st.1943-541x.0001311. 
[7] T. Brandurn-Nielsen, "Optimization of reinforcement in shells, folded plates, walls and slabs," ACI J. Proc., vol. 82, no. 3, pp. 304309, 1985.

[8] A. K. Gupta, "Combined membrane and flexural reinforcement in plates and shells," J. Struct. Div., vol. 112, no. 3, pp. 550-557, 1986.

[9] P. B. Lourenço and J. A. Figueiras, "Automatic design of reinforcement in concrete plates and shells," Eng. Comput., vol. 10, no. 6, pp. 519-541, 1993.

[10] Comité Euro-International du Betón, Model Code 1990, 1993.

[11] Comité Euro-International du Betón, Model Code 2010, 2013.

[12] A. B. Colombo, J. C. Della Bella, and T. N. Bittencourt, "An algorithm for the automatic design of concrete shell reinforcement," IBRACON Struct. Mater. J., vol. 7, no. 1, pp. 53-67, 2014.

[13] J. Kollegger, M. Azevedo, P. Kinzler, and A. Schirp, "Automated design procedure for reinforced concrete plates and shells," in Proc. Comput. Model. Concr. Struct., 1998, pp. 959-967.

[14] Comité Euro-International du Betón, Bulletin 45: Practitioners' Guide to Finite Element Modelling of Reinforced Concrete Structures, 2013.

[15] T. Baumann, "Zur Frage der Netzbewehrung von Flächentragwerken," Bauingenieur, vol. 47, no. 10, pp. 367-377, 1972.

[16] A. K. Gupta, "Membrane reinforcement in shells," J. Struct. Div., vol. 107, no. 1, pp. 41-56, 1981.

[17] F. J. Vecchio and M. P. Collins, "The modified compression-field theory for reinforced concrete elements subjected to shear," $A C I J$, vol. 83, no. 2, pp. 219-231, 1986.

Author contributions: MVC: literature review, practical examples, discussions, conclusions, writing and translation; TNB and JCDB: advisory and review.

Editors: Ricardo Carrazedo, José Luiz Antunes de Oliveira e Sousa, Guilherme Aris Parsekian. 